$$
\text { DOE/PC/95251-- T2 }
$$

\title{
SECOND GENERATION ADVANCED REBURNING FOR HIGH EFFICIENCY NOx CONTROL
}

Progress Report No. 2 for Period

January 1 - March 31, 1996

\author{
By: \\ Vladimir M. Zamansky \\ Energy and Environmental Research Corporation \\ 18 Mason, Irvine, CA 92718
}

DOE Contract No. DE-AC22-95PC95251

Phase I

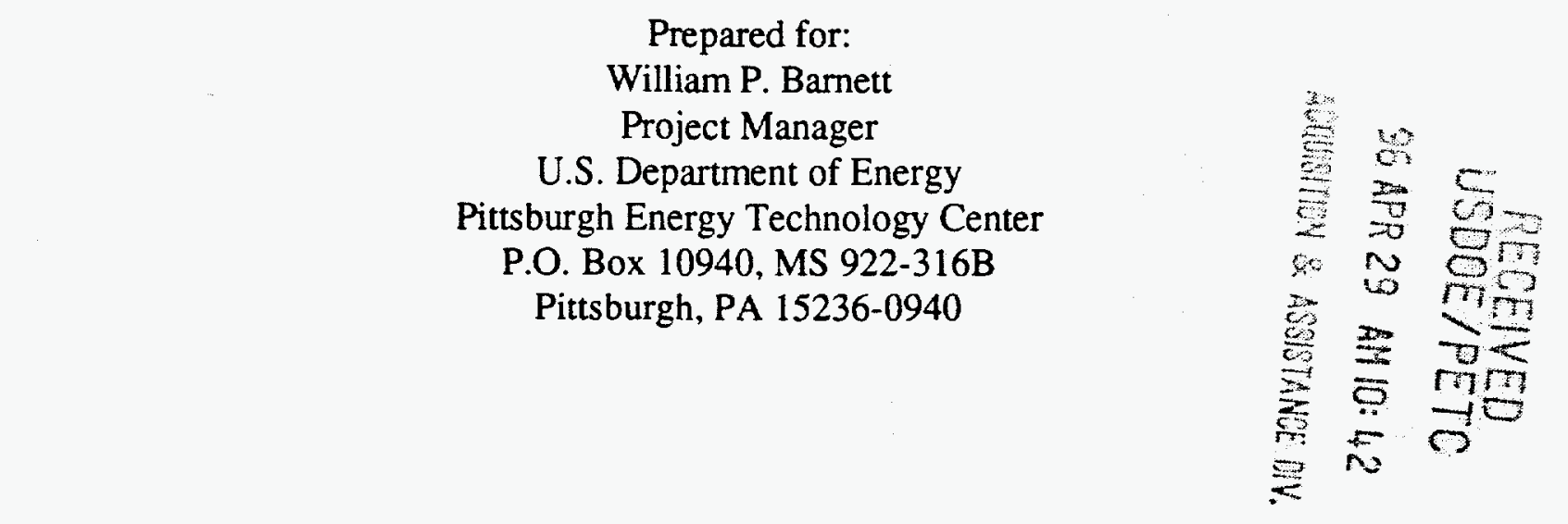

MASTER

April 25, 1996 


\section{DISCLAIMER}

Portions of this document may be illegible in electronic image products. Images are produced from the best available original document. 


\section{TABLE OF CONTENTS}

Section

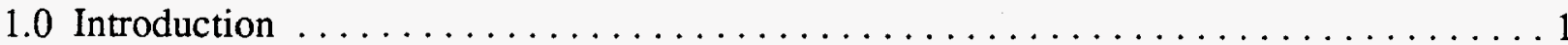

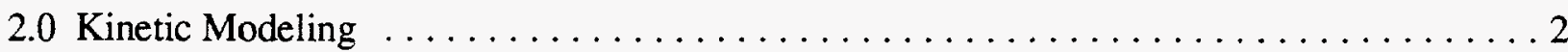

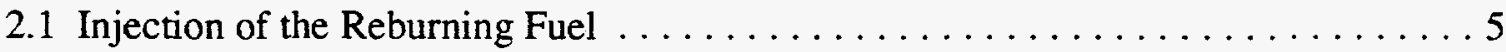

2.2 Injection of Ammonia into the Reburning Zone $\ldots \ldots \ldots \ldots \ldots \ldots \ldots \ldots$

2.3 Promotion of the $\mathrm{NO}^{-\mathrm{NH}_{3}}$ Interaction in the Reburning Zone $\ldots \ldots \ldots \ldots 23$

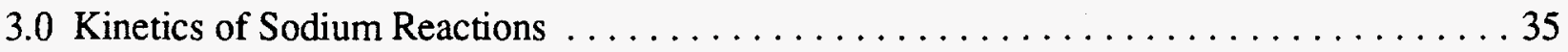

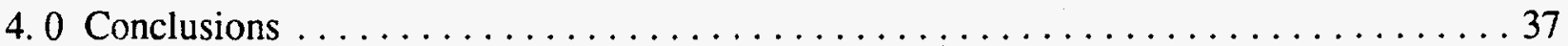

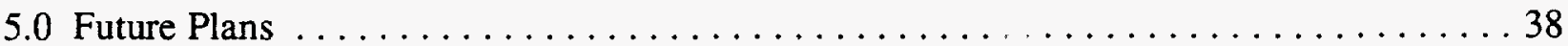

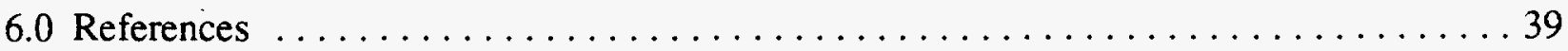

DISCLAIMER

This report was prepared as an account of work sponsored by an agency of the United States Government. Neither the United States Government nor any agency thereof, nor any of their employees, makes any warranty, express or implied, or assumes any legal liability or responsibility for the accuracy, completeness, or usefulness of any information, apparatus, product, or process disclosed, or represents that its use would not infringe privately owned rights. Reference herein to any specific commercial product, process, or service by trade name, trademark, manufacturer, or otherwise does not necessarily constitute or imply its endorsement, recommendation, or favoring by the United States Government or any agency thereof. The views and opinions of authors expressed herein do not necessarily state or reflect those of the United States Government or any agency thereof. 


\section{LIST OF FIGURES}

Eigure

Page

Figure 2.1 SGAR schematic - definitions $\ldots \ldots \ldots \ldots \ldots \ldots \ldots \ldots \ldots \ldots \ldots \ldots$

Figure 2.1.1. Kinetic curves of the main species in the reburning zone at $\mathrm{SR}_{2}=0.99 \ldots \ldots$

Figure 2.1.2. Kinetic curves of the main species in the reburning zone at $\mathrm{SR}_{2}=0.95 \ldots \ldots$

Figure 2.1.3. Kinetic curves of the main species in the reburning zone at $\mathrm{SR}_{2}=0.90 \ldots \ldots$

Figure 2.1.4. Kinetic curves in the reburning zone at $\mathrm{SR}_{2}=0.99, \mathrm{~T}_{1}=1700 \mathrm{~K}$, and $\mathrm{t}=5 \mathrm{~ms} \ldots 10$

Figure 2.1.5. Kinetic curves in the reburning zone at $\mathrm{SR}_{2}=0.90, \mathrm{~T}_{1}=1700 \mathrm{~K}$, and $\mathrm{t}=5 \mathrm{~ms} \ldots 11$

Figure 2.1.6. Modeling and experimental data on concentrations of $\mathrm{NO}, \mathrm{NH}_{3}, \mathrm{HCN}$, and TFN in the

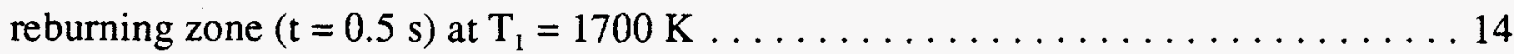

Figure 2.1.7. Modeling data on concentrations of $\mathrm{NO}, \mathrm{NH}_{3}, \mathrm{HCN}$, and TFN in the reburning zone

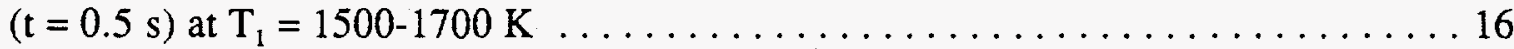

Figure 2.2.1. Effect of ammonia co-injection with the reburning fuel and $0.1 \mathrm{~s}$ delayed $\mathrm{NH}_{3}$ injection

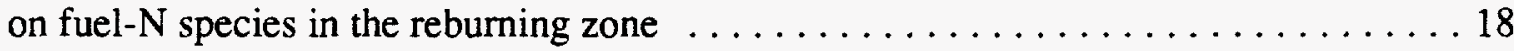

Figure 2.2.2. Effect of the delay time of $\mathrm{NH}_{3}$ injection into the reburning zone $\ldots \ldots \ldots$

Figure 2.2.3. Effect of the $\mathrm{NH}_{3}$ concentration injected into the reburning zone $\ldots \ldots \ldots 20$

Figure 2.2.4. Effect of ammonia in the reburning zone at $\mathrm{SR}_{2}=0.99 \ldots \ldots \ldots \ldots$

Figure 2.3.1. Effect of $\mathrm{NH}_{3}$ injection temperature and $\mathrm{NH}_{3}$ concentration in mixture $\mathrm{I} \ldots 24$

Figure 2.3.2. Effect of oxygen co-injection with $500 \mathrm{ppm} \mathrm{NH}_{3}$ into mixture $\mathrm{I} \ldots \ldots \ldots$

Figure 2.3.3. Effect of radicals co-injection with $500 \mathrm{ppm} \mathrm{NH}_{3}$ into mixture $\mathrm{I}, \ldots \ldots \ldots$

Figure 2.3.4. Modeling of the promotion effect at different predexponential factors A . . . . . 29

Figure 2.3.5. Comparison of the promotion effect of different compounds $\ldots \ldots \ldots . \ldots 30$

Figure 2.3.6. Optimum conditions for $\mathrm{NO}$ removal at $\mathrm{SR}_{2}=0.99 \ldots \ldots \ldots \ldots \ldots \ldots$

Figure 2.3.7. Efficiency of reburning at $\mathrm{SR}_{2}=0.90$ and $\mathrm{T}_{1}=1700 \mathrm{~K}$ depending on different $\mathrm{O}_{2}$

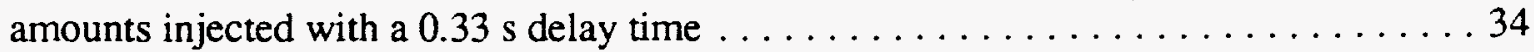




\section{LIST OF TABLES}

Table

Page

Table 2.1.1. Concentrations of methane injected into the reburning zone. $\ldots \ldots \ldots \ldots \ldots 5$

Table 2.1.2. Comparison of $\mathrm{NO}$ reaction rates with $\mathrm{C}$-radicals at $\mathrm{SR}_{2}=0.99 \ldots \ldots \ldots \ldots 12$

Table 2.1.3. Comparison of $\mathrm{NO}$ reaction rates with $\mathrm{C}$-radicals at $\mathrm{SR}_{2}=0.90 \ldots \ldots \ldots \ldots 13$ 


\subsection{Introduction}

Existing $\mathrm{NO}_{x}$ control technologies have limitations which may prevent them from successfully achieving commercial, cost effective application in the near future. This project develops a family of novel $\mathrm{NO}_{x}$ control technologies, Second Generation Advanced Reburning (SGAR), which have a potential to achieve $90+\% \mathrm{NO}_{x}$ control at a significantly lower cost than SCR.

Phase I consists of six tasks:

Task 1.1 Project Coordination and Reporting/Deliverables

T? : 1.2 Kinetics of $\mathrm{Na}_{2} \mathrm{CO}_{3}$ Reactions with Flue Gas Components

Task $1.30 .1 \times 10^{6} \mathrm{Btu} / \mathrm{hr}$ Optimization Studies

Task $1.41 .0 \times 10^{6} \mathrm{Btu} / \mathrm{hr}$ Process Development Tests

Task 1.5 Mechanism Development and Modeling

Task 1.6 Design Methodology and Application

During the first reporting period (October 1 - December 31, 1995), the Phase I Project Management Plan was prepared and the Kick-off meeting was performed at PETC. The bench-scale facility, 0.1 MBtu/hr Controlled Temperature Tower (CTT), was prepared for the experimental program (Task 1.3). Modeling (Task 1.5) was focused on selection of a $\mathrm{C}-\mathrm{H}-\mathrm{O}-\mathrm{N}$ chemical mechanism for description of the process chemistry.

This second reporting period (January 1 - March 31, 1996) included both modeling and experimental activities. Modeling was focused on evaluation of ammonia injection into the reburning zone and on the effect of various additives on promotion of the $\mathrm{NO}-\mathrm{NH}_{3}$ interaction in the reburning zone. First bench scale CTT experiments have been performed on different variants of the AR technology. The tests are continued, and the results will be reduced and reported in the next quarter. According to the project plan, a study on high-temperature reactions of sodium promoters (Task 1.2) has to be performed at the University of Texas in Austin (UT). Subcontract negotiations between EER and UT have been completed, and the UT team started their research. 


\subsection{Kinetic Modeling}

As was described in the 1st quarterly report (Zamansky and Maly, 1996), a detailed C-H-O-N kinetic mechanism was selected for modeling. The mechanism is based on the recently issued Version 2.11 of GRI-Mech (Bowman, Hanson et al., 1995) and includes SNCR reactions suggested by Bowman, 1995. The mechanism was presented in Appendix I of the 1st quarterly report verified by comparison with available experimental data on the Thermal DeNOx process.

During the current reporting period, modeling activities were continued with the use of the selected $\mathrm{C}-\mathrm{H}-\mathrm{O}-\mathrm{N}$ mechanism. The following issues were addressed:

- modeling of reburning with various stoichiometric ratios in the reburning zone;

- variation of reburning fuel (RF) injection temperature;

- delayed ammonia injection into the reburning zone;

- promotion of the $\mathrm{NO}-\mathrm{NH}_{3}$ interaction in the reburning zone.

The CHEMKIN-II kinetic program developed at the Sandia National Laboratories (Kee et al., 1989) was used for modeling. Calculations were performed without any adjustments in rate constants taking into account an actual BSF (Boiler Simulator Facility) temperature profile which is expected to be about $300 \mathrm{~K} / \mathrm{s}$ in the reburning zone.

Figure 2.1 reminds the nomenclature to refer to the various regions of the Second Generation Advanced Reburning (SGAR) process. The region upstream of the reburning fuel injection is referred to as the "primary zone". The primary zone Stoichiometric Ratio $\left(\mathrm{SR}_{1}\right)$ is maintained at $\mathrm{SR}_{1}=1.1$ for all tests and the initial NO concentration in this zone is referred to by a single subscript "i". The region between the reburning fuel and overfire air (OFA) injection is referred to as the "reburning zone". The reburning fuel is injected at a temperature of $T_{1}$. The first $\mathrm{N}$-agent $\left(A_{1}\right)$ is introduced at $T_{2}$ with a Nitrogen Stoichiometric molar Ratio $N_{S R}=A_{1} / N_{i}$ into the reburn zone, this zone is divided into two fuel rich zones with stoichiometries $\mathrm{SR}_{2}$ and $\mathrm{SR}_{3}$. NO concentration upstream of the first $\mathrm{N}$-agent injection is referred to as "ii". NO reduction from $\mathrm{NO}_{\mathrm{i}}$ to $\mathrm{NO}_{\mathrm{i}}$ is caused by 


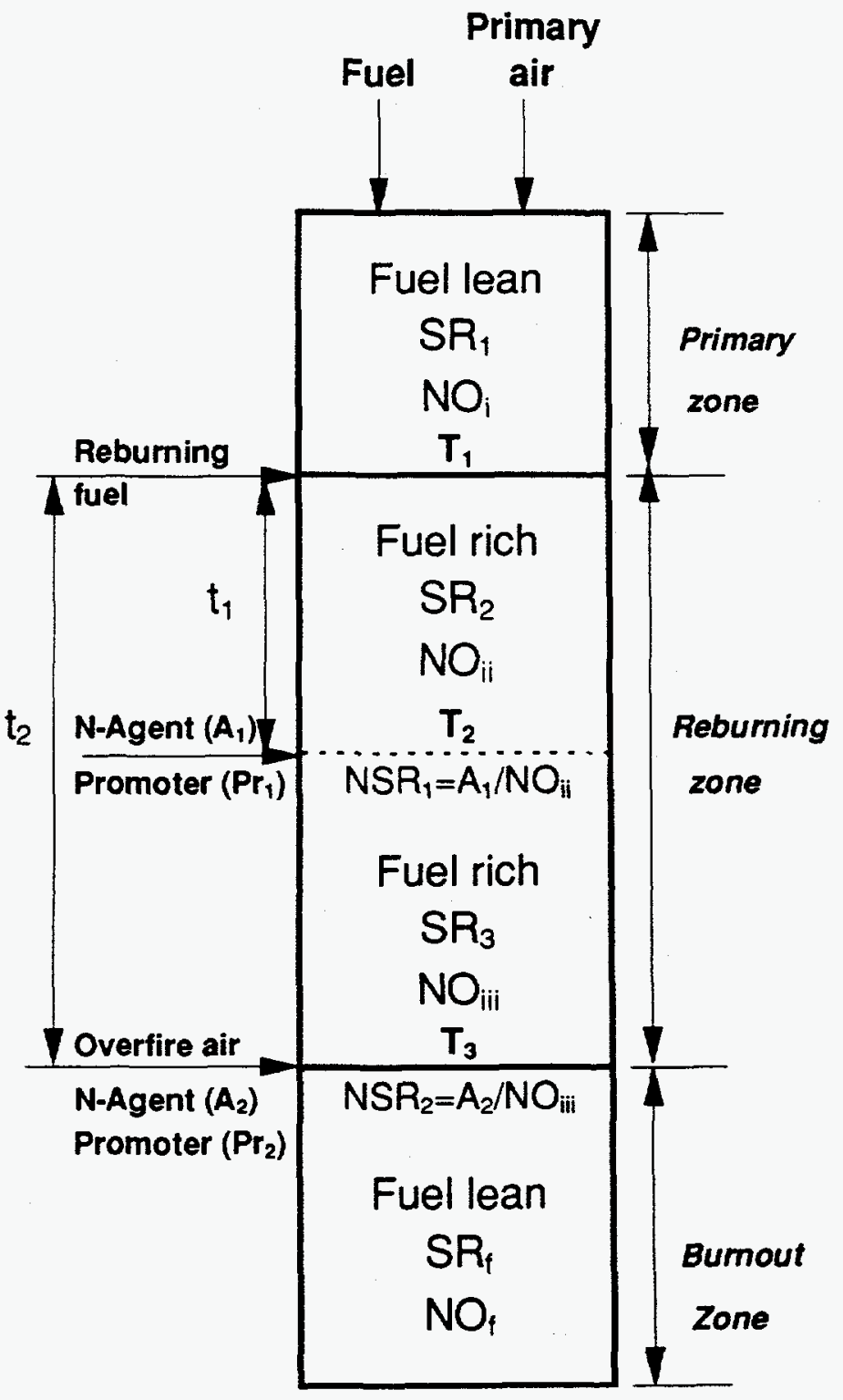

Figure 2.1 SGAR schematic - definitions. 
reburning only. The first $\mathrm{N}$-agent is injected with or without promoters $\left(\operatorname{Pr}_{1}\right)$ with $\mathrm{t}_{1}$ delay time after RF injection. NO concentration downstream of the $A_{1}$ injection is called $\mathrm{NO}_{\mathrm{im}}$, and $\mathrm{NO}$ reduction from $\mathrm{NO}_{\mathrm{i}}$ to $\mathrm{NO}_{\text {ii }}$ is caused by the first $\mathrm{N}$-agent. Overfire air is injected at $\mathrm{T}_{3}$ with a $\mathrm{t}_{2}$ delay time after RF injection. OFA is a career gas for injecting the second $\mathrm{N}$-agent $\left(\mathrm{A}_{2}\right)$ which is injected with or without promoters $\left(\mathrm{Pr}_{2}\right) . \mathrm{A}_{2}$ is injected with $\mathrm{NSR}_{2}=\mathrm{A}_{2} / \mathrm{NO}_{\text {iii. }}$. The downstream region is referred to as the "burnout zone". Stoichiometric ratio in this zone is $\mathrm{SR}_{\mathrm{f}}$, and the final NO concentration is $\mathrm{NO}_{\mathrm{f}}$.

Modeling of the SGAR process is a multi-parametric task. SGAR includes injections of 6 different components, and each injection depends on several parameters. These injections and associated parameters, varied in modeling, are the following:

1. Injection of the reburning fuel $\left(\mathrm{CH}_{4}\right.$ is considered in modeling)

- heat input $\left(\mathrm{SR}_{2}\right)$;

- injection temperature $\left(T_{1}\right)$.

2. $\mathrm{N}$-agent injection into the reburning zone $\left(\mathrm{NH}_{3}\right.$ is considered in modeling)

- injection temperature $\left(T_{2}\right)$ or delay time $\left(t_{1}\right)$;

- N-agent amount $\left(A_{1}, N S R_{1}\right)$.

3. Promoter injection into the reburning zone

- promoter amount $\left(\mathrm{Pr}_{1}\right)$;

- mechanism of promotion.

4. $\mathrm{N}$-agent injection into the burnout zone $\left(\mathrm{NH}_{3}\right.$ is considered in modeling)

- injection temperature $\left(T_{3}\right)$ or delay time $\left(t_{2}\right)$;

- N-agent amount $\left(A_{2}, N_{S} R_{2}\right)$.

5. Promoter injection into the burnout zone

- promoter amount $\left(\mathrm{Pr}_{2}\right)$;

- mechanism of promotion.

6. OFA injection

- injection temperature $\left(T_{3}\right)$. 
A modeling approach was selected which makes it possible to model each injection separately and then optimize them simultaneously.

\subsection{Injection of the Reburning Fuel}

Stoichiometric ratio $S_{1}$ in the primary zone was kept at $S_{1}=1.1$ for all calculations. This $S_{1}$ corresponds to methane combustion with the following mixture composition:

\section{$8.72 \% \mathrm{CH}_{4}-19.18 \% \mathrm{O}_{2}$ - balance $\mathrm{N}_{2}$}

If the combustion process in the primary zone is complete, it generates about $8 \% \mathrm{CO}_{2}$ and $15 \% \mathrm{H}_{2} \mathrm{O}$. At the same time, $1.74 \% \mathrm{O}_{2}$ is left which is available for oxidation of the reburning fuel. Table 2.1.1 presents molar fractions of methane which are necessary to provide certain stoichiometric ratios in the reburning zone.

Table 2.1.1. Concentrations of methane injected into the reburning zone.

\begin{tabular}{|c|c|c|c|c|c|c|}
\hline $\mathrm{SR}_{2}$ & 1 & 0.99 & 0.95 & 0.90 & 0.80 & 0.70 \\
\hline$\left[\mathrm{CH}_{4}\right], \%$ & 0.87 & 0.967 & 1.37 & 1.94 & 3.27 & 4.98 \\
\hline
\end{tabular}

Thus, to provide a desirable $\mathrm{SR}_{2}$ in the reburning zone, one should select a certain $\left[\mathrm{CH}_{4}\right]$ from Table 2.1.1 and use the following mixture:

$$
\left[\mathrm{CH}_{4}\right]-1.74 \% \mathrm{O}_{2}-600 \mathrm{ppm} \mathrm{NO}-8 \% \mathrm{CO}_{2}-15 \% \mathrm{H}_{2} \mathrm{O}-\text { balance } \mathrm{N}_{2} \text {. }
$$

An initial $\mathrm{NO}$ concentration $\mathrm{NO}_{\mathrm{i}}=600 \mathrm{ppm}$ was used for calculations. Figures 2.1.1-2.1.3 demonstrate concentration profiles of main species in the reburning zone at an injection temperature $T_{1}=1700 \mathrm{~K}$ and $S R_{2}$ equals $0.99,0.95$, and 0.90 , respectively. Comparison of these graphs shows that $\mathrm{CH}_{4}$ is rapidly converted to $\mathrm{CO}$ and $\mathrm{H}_{2}$. Only at $\mathrm{SR}_{2}=0.90$, about $300 \mathrm{ppm} \mathrm{CH}_{4}$ is present in the mixture. At $\mathrm{SR}_{2}=0.99$ and 0.95 , the amount of $\mathrm{CH}_{4}$ is lower than $1 \mathrm{ppm}$. 


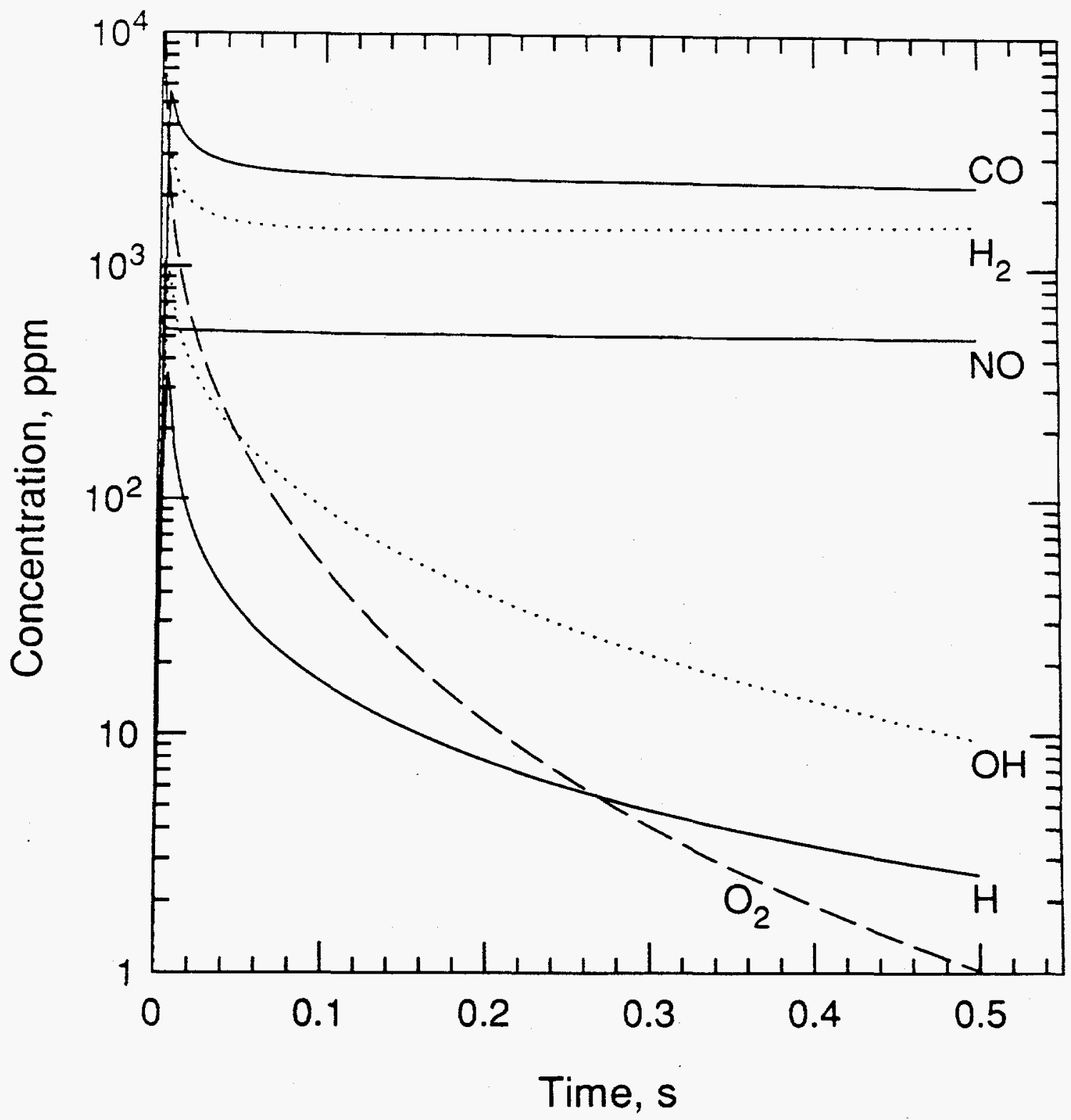

Figure 2.1.1. Kinetic curves of the main species in the reburning zone at $\mathrm{SR}_{2}=0.99$ and injection temperature $T_{1}=1700 \mathrm{~K}$. 


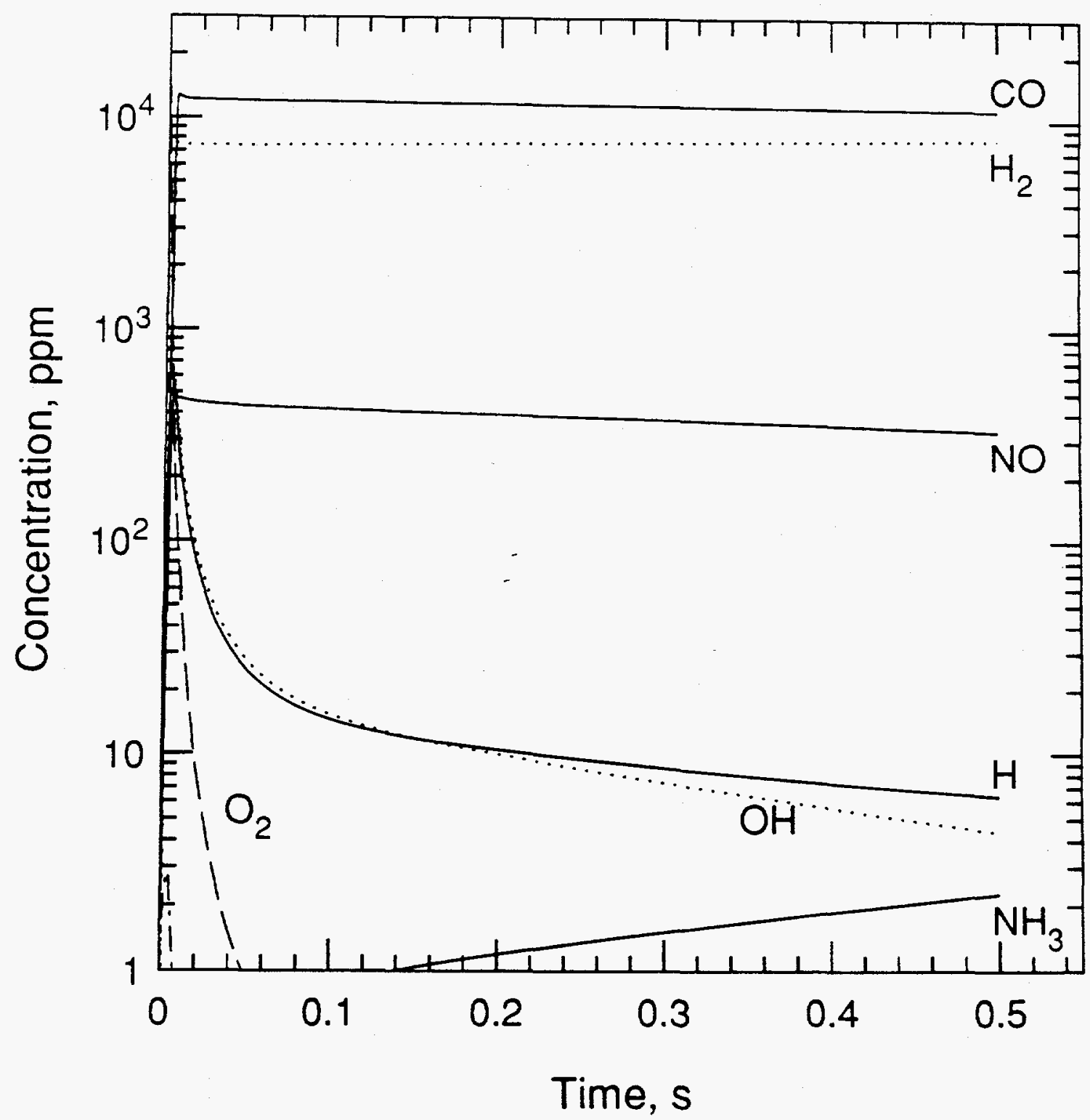

Figure 2.1.2. Kinetic curves of the main species in the reburning zone at $\mathrm{SR}_{2}=0.95$ and injection temperature $T_{1}=1700 \mathrm{~K}$. 


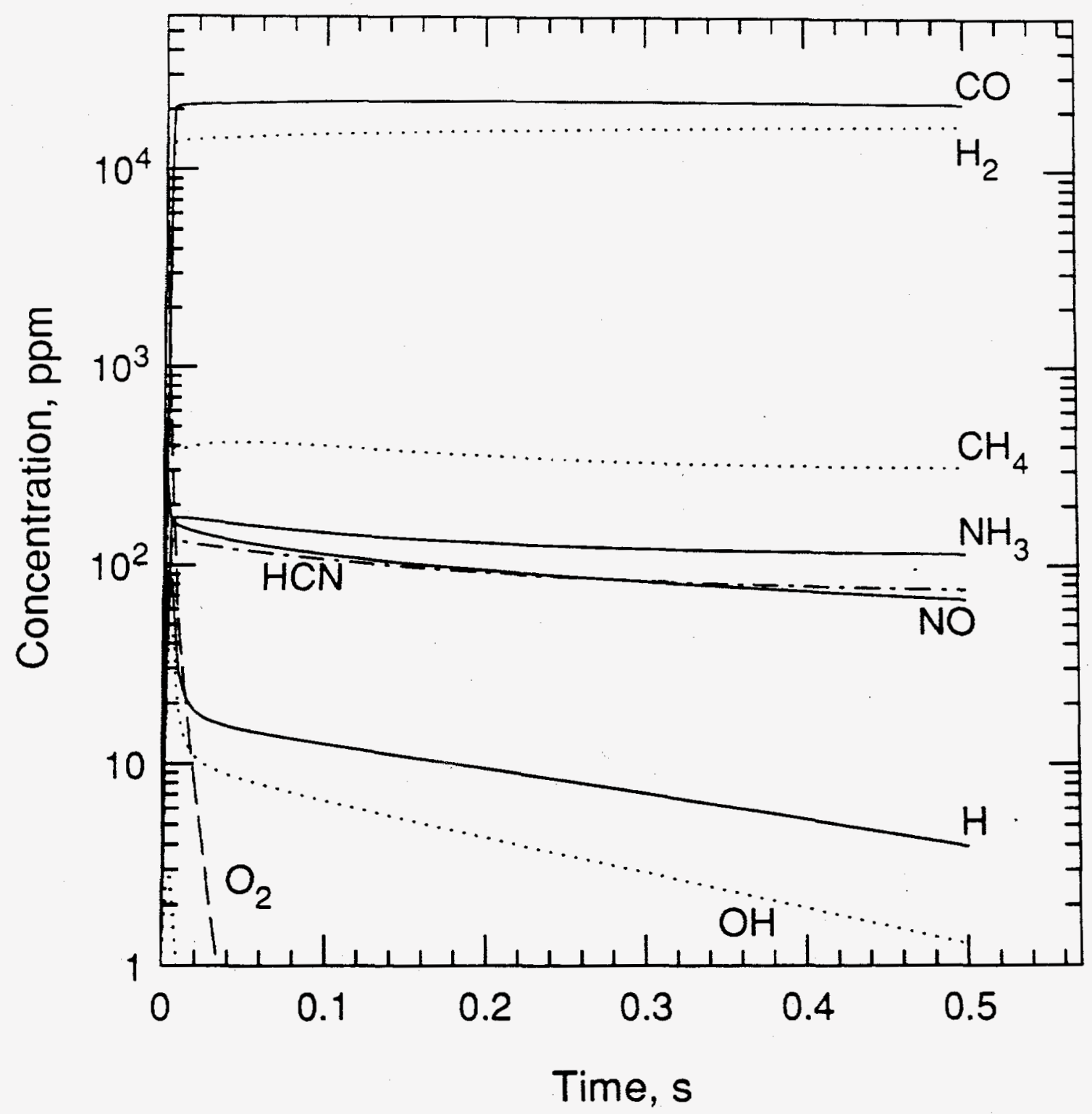

Figure 2.1.3. Kinetic curves of the main species in the reburning zone at $\mathrm{SR}_{2}=0.90$ and injection temperature $T_{1}=1700 \mathrm{~K}$. 
At $\mathrm{SR}_{2}=0.99$ (Figure 2.1.1), NO concentration drops during very short period of time from $600 \mathrm{ppm}$ to about $540 \mathrm{ppm}$ and then, slowly decreases to $502 \mathrm{ppm}$. Concentrations of $\mathrm{NH}_{3}$ and $\mathrm{HCN}$ are lower than $1 \mathrm{ppm}$, though some $\mathrm{O}_{2}$ is still present.

At $\mathrm{SR}_{2}=0.95$ (Figure 2.1.2), oxygen disappears within $0.05 \mathrm{~s}$, and $\mathrm{NH}_{3}$ concentration slowly increases. NO again rapidly drops to about $430 \mathrm{ppm}$ and decay slowly to $330 \mathrm{ppm}$. Total Fuel Nitrogen $\left(\mathrm{TFN}=\mathrm{NO}+\mathrm{NH}_{3}+\mathrm{HCN}\right)$ concentration is 332 ppm by $0.5 \mathrm{~s}$.

At $\mathrm{SR}_{2}=0.90$ (Figure 2.1.3), NO rapidly and more efficiently decreases from 600 to $160 \mathrm{ppm}$, and then slowly to $67 \mathrm{ppm}$. However, in this case, the mixture contains $75 \mathrm{ppm} \mathrm{HCN}$ and $115 \mathrm{ppm} \mathrm{NH}_{3}$ at $t=0.5$ s. Hence, TFN equals 257 ppm.

The results show that there are two steps of NO reduction in the reburning process: the first very fast step and the second slow step. The reason of these fast and slow decreases in NO concentration is of primary interest for understanding the reburning phenomenon. To clarify the main processes in the fast NO reduction zone, calculations were carried out with a reaction time of $5 \mathrm{msec}$ for $\mathrm{SR}_{2}=$ 0.99 and 0.90. Figures 2.1.4 and 2.1.5 represent the results.

Figure 2.1.4 demonstrates kinetic curves in the reburning zone at $\mathrm{SR}_{2}=0.99, \mathrm{~T}_{1}=1700 \mathrm{~K}$, and $\mathrm{t}=$ $5 \mathrm{~ms}$. The NO concentration has even a little minimum at about $2 \mathrm{~ms}$. This minimum is explained by reactions of $\mathrm{NO}$ with $\mathrm{C}$-containing radicals: $\mathrm{CH}_{3}, \mathrm{CH}_{2}, \mathrm{HCCO}, \mathrm{CH}_{2}(\mathrm{~S}), \mathrm{CH}$, and $\mathrm{C}$. The radicals are formed from $\mathrm{CH}_{3}$ which, in turn, is formed from $\mathrm{CH}_{4}$. The radicals participate also in recombination reactions with each other and in reactions with oxygen and other species. As a result of these processes, concentrations of the radicals increase within $2 \mathrm{~ms}$, and then, since all $\mathrm{CH}_{4}$ is consumed and there is no more feed, the concentration of $\mathrm{C}$-radicals reduces, due to recombination and oxidation, by several orders of magnitude. Concentrations of $\mathrm{HCN}$ and $\mathrm{NH}_{3}$ rise simultaneously with C-radicals because $\mathrm{HCN}$ and $\mathrm{NH}_{3}$ are the main molecules formed due to reactions of the radicals with NO. At about $2 \mathrm{~ms}$, both $\mathrm{HCN}$ and $\mathrm{NH}_{3}$ are oxidized by existing oxygen into NO. Therefore, the NO concentration slightly increases. It is of interest to note that concentrations of $\mathrm{CH}_{2}$ and $\mathrm{HCCO}$ reach $8-9 \mathrm{ppm}$, though $\mathrm{CH}$ concentration does not exceed $0.1 \mathrm{ppm}$. Main reactions of NO 

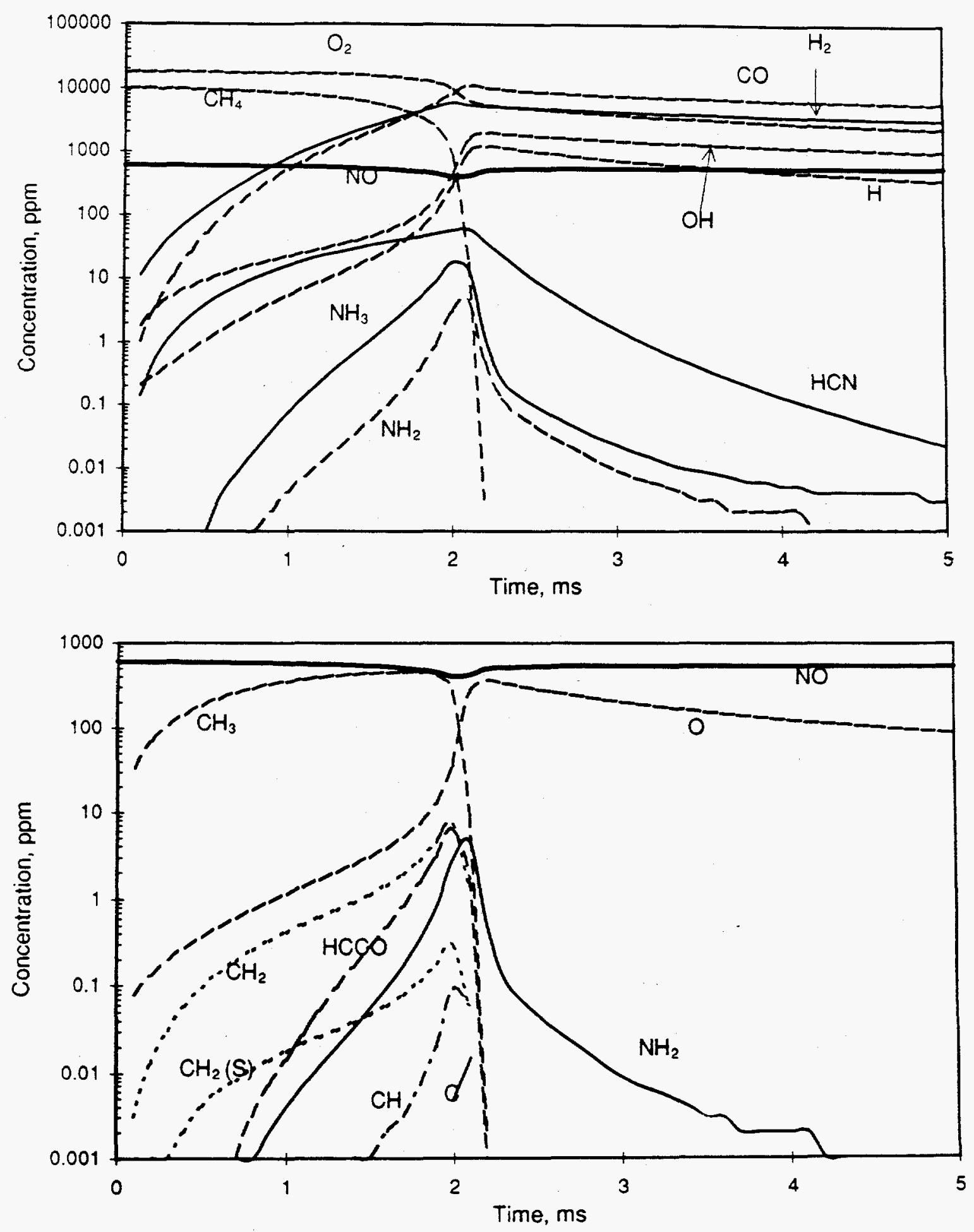

Figure 2.1.4. Kinetic curves in the reburning zone at $S R_{2}=0.99, T_{1}=1700 \mathrm{~K}$, and $\mathrm{t}=5 \mathrm{~ms}$. 

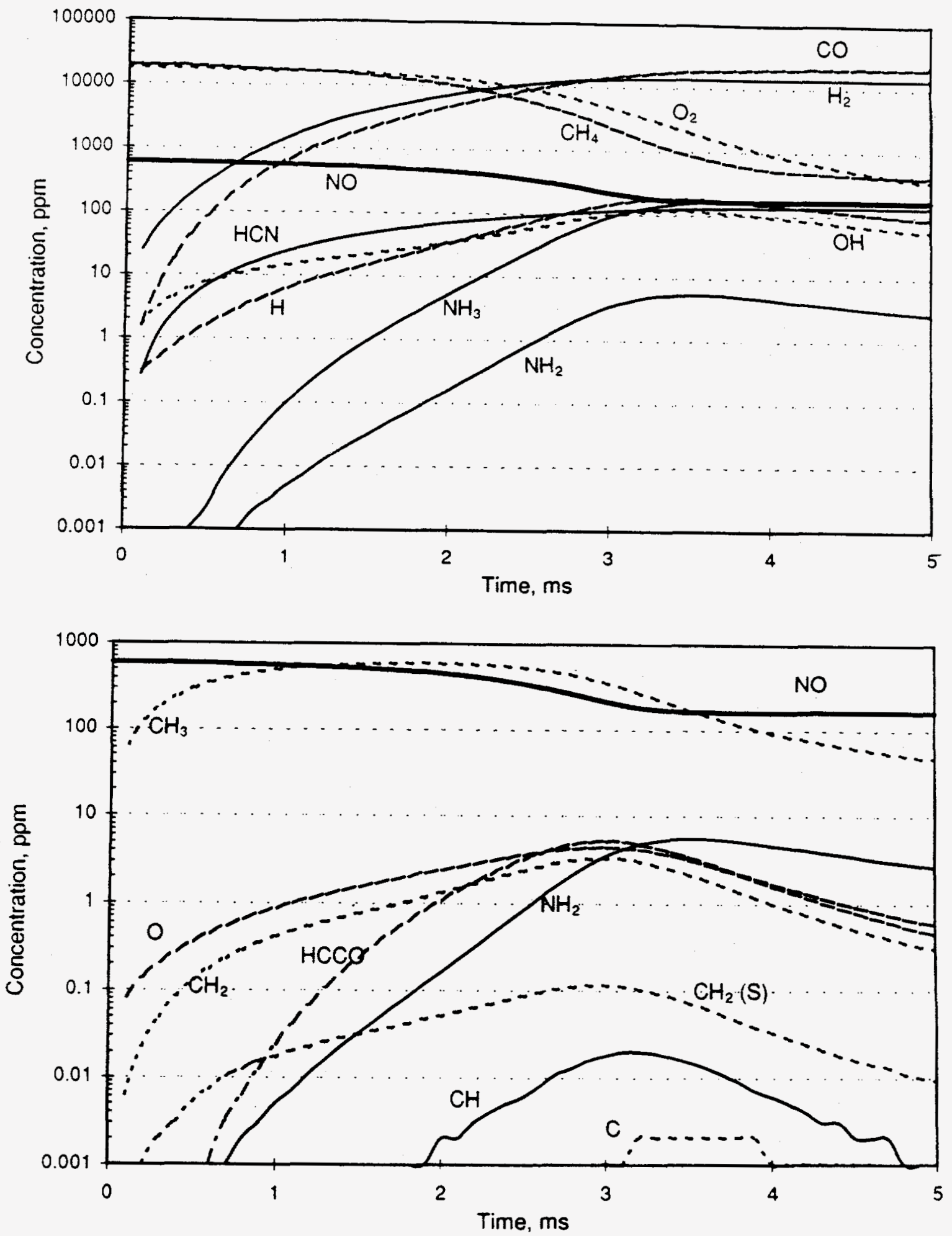

Figure 2.1.5. Kinetic curves in the reburning zone at $\mathrm{SR}_{2}=0.90, \mathrm{~T}_{1}=1700 \mathrm{~K}$, and $\mathrm{t}=5 \mathrm{~ms}$. 
removal can oe compared by considering their rates at the maximum point of radical concentrations. Table 2.1.2 presents the NO reactions with C-radicals and their rates in arbitrary units at 2 ms.

Table 2.1.2. Comparison of $\mathrm{NO}$ reaction rates with $\mathrm{C}$-radicals at $\mathrm{SR}_{2}=0.99, \mathrm{~T}_{1}=1700 \mathrm{~K}$ and $\mathrm{t}=2 \mathrm{~ms}$.

\begin{tabular}{|c|c|c|c|c|}
\hline C-radical & Reaction & Rate, arb. units & Total rate, a. u. & Rank \\
\hline C & $\begin{aligned} \mathrm{C}+\mathrm{NO} & =\mathrm{CN}+\mathrm{O} \\
& =\mathrm{CO}+\mathrm{N}\end{aligned}$ & $\begin{array}{c}1 \\
1.6\end{array}$ & 2.6 & 6 \\
\hline $\mathrm{CH}$ & $\begin{aligned} \mathrm{CH}+\mathrm{NO} & =\mathrm{HCN}+\mathrm{O} \\
& =\mathrm{H}+\mathrm{NCO} \\
& =\mathrm{N}+\mathrm{HCO}\end{aligned}$ & $\begin{array}{l}25 \\
10 \\
16\end{array}$ & 51 & 4 \\
\hline $\mathrm{CH}_{2}$ & $\begin{aligned} \mathrm{CH}_{2}+\mathrm{NO} & =\mathrm{H}+\mathrm{HNCO} \\
& =\mathrm{OH}+\mathrm{HCN} \\
& =\mathrm{H}+\mathrm{HCNO}-\end{aligned}$ & $\begin{array}{l}560 \\
140 \\
200\end{array}$ & 900 & 2 \\
\hline $\mathrm{CH}_{2}(\mathrm{~S})$ & $\begin{aligned} \mathrm{CH}_{2}(\mathrm{~S})+\mathrm{NO} & =\mathrm{H}+\mathrm{HNCO} \\
& =\mathrm{OH}+\mathrm{HCN} \\
& =\mathrm{H}+\mathrm{HCNO}\end{aligned}$ & $\begin{array}{c}14 \\
3.6 \\
5\end{array}$ & 22.6 & 5 \\
\hline $\mathrm{CH}_{3}$ & $\begin{aligned} \mathrm{CH}_{3}+\mathrm{NO} & =\mathrm{HCN}+\mathrm{H}_{2} \mathrm{O} \\
& =\mathrm{H}_{2} \mathrm{CN}+\mathrm{OH}\end{aligned}$ & $\begin{array}{l}71 \\
5.6 \\
\end{array}$ & 76.6 & 3 \\
\hline $\mathrm{HCCO}$ & $\mathrm{HCCO}+\mathrm{NO}=\mathrm{HCNO}+\mathrm{CO}$ & 1860 & 1860 & 1 \\
\hline
\end{tabular}

This comparison shows that $\mathrm{HCCO}$ radicals, followed by $\mathrm{CH}_{2}$ radicals, are the most important species depleting NO concentration. Thus, the reactions of $\mathrm{HCCO}$ and $\mathrm{CH}_{2}$ radicals are dominant pathways (in the scope of the assumed mechanism) for NO consumption during the initial fast NO removal after RF injection under the conditions examined.

Figure 2.1.5 shows kinetic curves in the reburning zone within first $5 \mathrm{~ms}$ at $\mathrm{SR}_{2}=0.90$ and $\mathrm{T}_{1}=$ $1700 \mathrm{~K}$. NO concentration decreases from 600 to $165 \mathrm{ppm}$, and this is explained by reactions of NO with the same C-containing radicals. Concentrations of the radicals also have a maximum, in this case at about $3 \mathrm{~ms}$, but they are removed not so rapidly since $\mathrm{CH}_{4}$ concentration is much higher, and the 
source of the radicals $\left(\mathrm{CH}_{4}\right.$ and $\left.\mathrm{CH}_{3}\right)$ still exists within $5 \mathrm{~ms}$. Concentrations of $\mathrm{HCN}$ and $\mathrm{NH}_{3}$ again rise simultaneously with C-radicals, but, in this case, $\mathrm{HCN}$ and $\mathrm{NH}_{3}$ are almost not oxidized since $\mathrm{O}_{2}$ concentration drops rapidly (only $1 \mathrm{ppm} \mathrm{O}_{2}$ exists in the mixture in $30 \mathrm{~ms}$ ).

Table 2.1.3 contains reaction rates for the NO reactions with $\mathrm{C}$-radicals at $\mathrm{SR}_{2}=0.90$ at the maximum point of radical concentrations $(3 \mathrm{~ms})$. The same conclusion can be made: importance of NO removing radicals decreases in the row: $\mathrm{HCCO}, \mathrm{CH}_{2}, \mathrm{CH}_{3}, \mathrm{CH}, \mathrm{CH}_{2}(\mathrm{~S})$, and $\mathrm{C}$.

Table 2.1.3. Comparison of $\mathrm{NO}$ reaction rates with $\mathrm{C}$-radicals at $\mathrm{SR}_{2}=0.90, \mathrm{~T}_{1}=1700 \mathrm{~K}$ and $\mathrm{t}=3 \mathrm{~ms}$.

\begin{tabular}{|c|c|c|c|c|}
\hline C-radical & Reaction & Rate, arb. units & Total rate, a. u. & Rank \\
\hline C & $\begin{aligned} \mathrm{C}+\mathrm{NO} & =\mathrm{CN}+\mathrm{O} \\
& =\mathrm{CO}+\mathrm{N}\end{aligned}$ & $\begin{array}{c}1 \\
1.6\end{array}$ & 2.6 & 6 \\
\hline $\mathrm{CH}$ & $\begin{aligned} \mathrm{CH}+\mathrm{NO} & =\mathrm{HCN}+\mathrm{O} \\
& =\mathrm{H}+\mathrm{NCO} \\
& =\mathrm{N}+\mathrm{HCO}\end{aligned}$ & $\begin{array}{l}25 \\
10 \\
16\end{array}$ & 51 & 4 \\
\hline $\mathrm{CH}_{2}$ & $\begin{aligned} \mathrm{CH}_{2}+\mathrm{NO} & =\mathrm{H}+\mathrm{HNCO} \\
& =\mathrm{OH}+\mathrm{HCN} \\
& =\mathrm{H}+\mathrm{HCNO}\end{aligned}$ & $\begin{array}{l}553 \\
139 \\
196\end{array}$ & 888 & 2 \\
\hline $\mathrm{CH}_{2}(\mathrm{~S})$ & $\begin{aligned} \mathrm{CH}_{2}(\mathrm{~S})+\mathrm{NO} & =\mathrm{H}+\mathrm{HNCO} \\
& =\mathrm{OH}+\mathrm{HCN} \\
& =\mathrm{H}+\mathrm{HCNO}\end{aligned}$ & $\begin{array}{l}16 \\
4.0 \\
5.6\end{array}$ & 25.6 & 5 \\
\hline $\mathrm{CH}_{3}$ & $\begin{aligned} \mathrm{CH}_{3}+\mathrm{NO} & =\mathrm{HCN}+\mathrm{H}_{2} \mathrm{O} \\
& =\mathrm{H}_{2} \mathrm{CN}+\mathrm{OH}\end{aligned}$ & $\begin{array}{c}200 \\
16 \\
\end{array}$ & 216 & 3 \\
\hline $\mathrm{HCCO}$ & $\mathrm{HCCO}+\mathrm{NO}=\mathrm{HCNO}+\mathrm{CO}$ & 2940 & 2940 & 1 \\
\hline
\end{tabular}

Figure 2.1.6 compares modeling and experimental data on concentrations of $\mathrm{NO}, \mathrm{NH}_{3}, \mathrm{HCN}$, and TFN in the reburning zone $(t=0.5 \mathrm{~s})$ at $T_{1}=1700 \mathrm{~K}$ for different $R F$ concentrations (various $S_{2}$ ). The main difference between the experimental and modeling data sets is observed at low $\mathrm{SR}_{2}$ where modeling predicts higher $\mathrm{NH}_{3}$ concentration, but experiment demonstrates higher $\mathrm{HCN}$ level. 

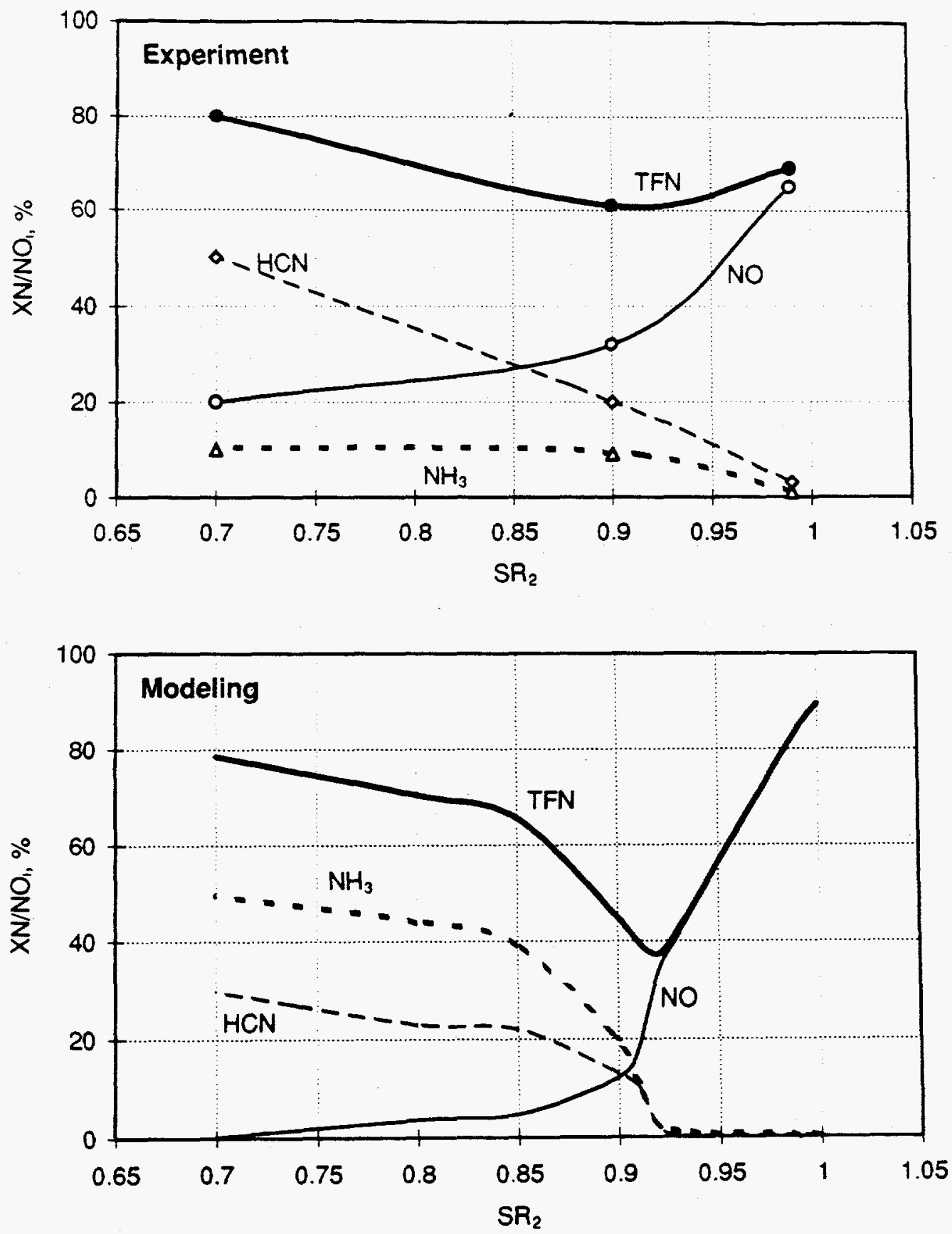

Figure 2.1.6. Modeling and experimental data on concentrations of $\mathrm{NO}, \mathrm{NH}_{3}, \mathrm{HCN}$, and TFN in the reburning zone $(t=0.5 \mathrm{~s})$ at $T_{1}=1700 \mathrm{~K}$ for different concentrations of reburning fuel, $\mathrm{SR}_{2}$. 
However, at $\mathrm{SR}_{2}=0.90-0.99$, experimental and modeling concentrations are close to each other. It worth noting that experimental data can, of course, be affected by the rate of mixing which is instant in modeling.

Figure 2.1.6 demonstrates the current level of confidence in kinetic mechanisms developed for modeling of reburning. A lot of work needs to be done to improve the model, but the model can predict major reaction trends and can help to find prospective conditions of NO removal. These conditions should be, of course, optimized by experiments.

Figure 2.1.7 compares performance of the reburning process at different temperatures for $\mathrm{SR}_{2}=0.99$, 0.95 , and 0.90 . Under conditions close to stoichiometry, $\mathrm{SR}_{2}=0.99$, concentrations of $\mathrm{NH}_{3}$ and $\mathrm{HCN}$ in the reburning zone are less than $1 \mathrm{ppm}$, and all TFN is in the form of NO. TFN concentration in the reburning zone is decreased by $20-30 \%$, and it is smaller at lower temperatures where C-radicals exist longer. Since they do not disappear too fast, more C-radicals are available for the reactions with NO. For instance, as shown in Figure 2.1.4, the first, fast reburning stage proceeds within $5 \mathrm{~ms}$ at $\mathrm{T}=1700 \mathrm{~K}$, mainly within $2 \mathrm{~ms}$. At $1500 \mathrm{~K}$, C-radicals do not disappear so fast, and the first stage proceeds longer, within about $20 \mathrm{~ms}$. As a result, NO concentration drops in this fast stage from 600 to $535 \mathrm{ppm}$ at $1700 \mathrm{~K}$, but at $1500 \mathrm{~K}$ the process is more efficient: NO decreases from 600 to $450 \mathrm{ppm}$.

At $\mathrm{SR}_{2}=0.95$ (Figure 2.1.7), only small amounts of $\mathrm{NH}_{3}$ and $\mathrm{HCN}$ are formed at about $1500 \mathrm{~K}$, and most of TFN exists in the form of NO. TFN concentration again lower at low temperatures, and it is within $40-65 \%$ TFN reduction range. At $T_{1}=1500 \mathrm{~K}$, the fast reburning stage proceeds in about $30-40 \mathrm{~ms}$, much slower than at $1700 \mathrm{~K}(5 \mathrm{~ms})$. The slower reactions of C-radicals cause more efficient first reburning stage: NO concentration decreases from 600 to $475 \mathrm{ppm}$ and from 600 to 300 ppm at 1700 and $1500 \mathrm{~K}$, respectively.

At higher RF injection rate (Figure 2.1.7, $\mathrm{SR}_{2}=0.90$ ) most of $\mathrm{NO}$ is converted to $\mathrm{NH}_{3}$ and $\mathrm{HCN}$. Efficiency of TFN removal is $20-55 \%$, and, in the contrary to the previous cases, TFN removal is more efficient at higher temperatures. Explanation of this effect is straightforward. At $\mathrm{SR}_{2}=0.90$, 

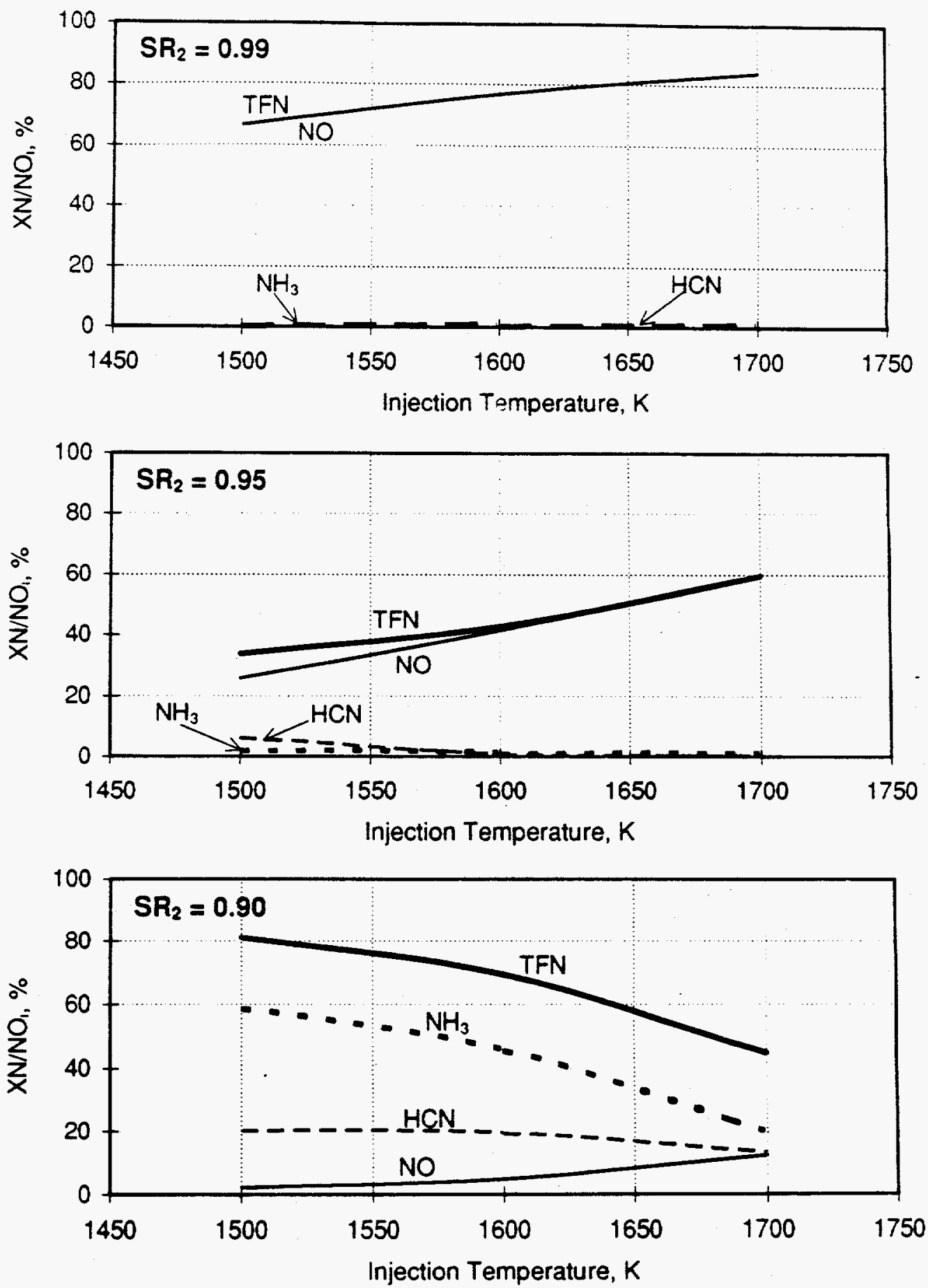

Figure 2.1.7. Modeling data on concentrations of $\mathrm{NO}, \mathrm{NH}_{3}, \mathrm{HCN}$, and TFN in the reburning zone $(t=0.5 \mathrm{~s})$ at $T_{1}=1500-1700 \mathrm{~K}$ for different concentrations of reburning fuel, $\mathrm{SR}_{2}$. 
the efficiency of NO removal continues to increase, as seen in Figure 2.1.7, and NO level is smaller at low temperatures. However, concentrations of $\mathrm{NH}_{3}$ and $\mathrm{HCN}$ are much higher than $\mathrm{NO}$, and they decrease at higher temperatures since they react faster. Therefore, TFN decreases at $\mathrm{T}=1700 \mathrm{~K}$.

Thus, modeling shows that at higher RF injection rates $\left(\mathrm{SR}_{2}\right.$ is about 0.90$)$, higher temperatures results in higher efficiency of TFN removal. At lower injection rates $\left(\mathrm{SR}_{2}=0.95-0.99\right)$, reburning efficiency is higher at lower temperatures. This effect can be checked and optimized by experimental testing.

\subsection{Injection of Ammonia into the Reburning Zone}

When fuel is added into the reburning zone, the oxygen disappears very fast in the reaction with the fuel to form $\mathrm{CO}$ and $\mathrm{H}_{2}$. If $\mathrm{N}$-agents (ammonia, urea, etc.) are injected into the reburning zone, they form $\mathrm{NH}_{\mathrm{i}}$ radicals $\left(\mathrm{NH}_{2}, \mathrm{NH}, \mathrm{N}\right)$ which are active in $\mathrm{NO}$ removal reactions. The $\mathrm{NH}_{\mathrm{i}}$ radicals can react either with $\mathrm{O}_{2}$ into $\mathrm{NO}$ or with $\mathrm{NO}$ into $\mathrm{N}_{2}$. The NO reduction process is effective if the $\mathrm{NH}_{i}$ precursors ( $\mathrm{N}$-agents) appear in the gas mixture when concentration of oxygen has been significantly depleted by the reburning fuel, thus preventing oxidation of $\mathrm{N}$-agents into NO. Calculated characteristic times for $\mathrm{O}_{2}$ disappearance after $\mathrm{RF}$ injection are less than $0.01 \mathrm{~s}$ at $1700 \mathrm{~K}$ and about $0.1 \mathrm{~s}$ at $1450 \mathrm{~K}$. The delay time between $\mathrm{RF}$ injection and the formation of $\mathrm{NH}_{\mathrm{i}}$ species should be close to these times for effective NO reduction.

Results of calculations which demonstrate the effect of the delayed ammonia injection on NO reduction by $\mathrm{CH}_{4}$ reburning are presented in Figure 2.2.1. The first graph shows concentrations of $\mathrm{NO}, \mathrm{NH}_{3}, \mathrm{HCN}$, and TFN after $0.5 \mathrm{~s}$ at different values of $\mathrm{SR}_{2}$ for injection of $600 \mathrm{ppm} \mathrm{NH}_{3}$ without delay, i.e. co-injection with the reburning fuel. At $\mathrm{SR}_{2}=0.90$, ammonia co-injection causes a decrease in TFN from $1200 \mathrm{ppm}\left(600 \mathrm{ppm} \mathrm{NO}\right.$ and $600 \mathrm{ppm} \mathrm{NH}$ ) to $327 \mathrm{ppm}$. At $\mathrm{SR}_{2}=0.90$, the concentration of the reburning fuel is high, and its reaction with the oxygen forms a large radical pool. The radicals initiate a rapid reaction between $\mathrm{NH}_{3}$ and $\mathrm{NO}$, and the TFN concentration is depleted. This reaction requires a small amount of oxygen, to support the radical pool, and this amount is available in the mixture during the first rapid reaction stage. Concentration of ammonia decreases 

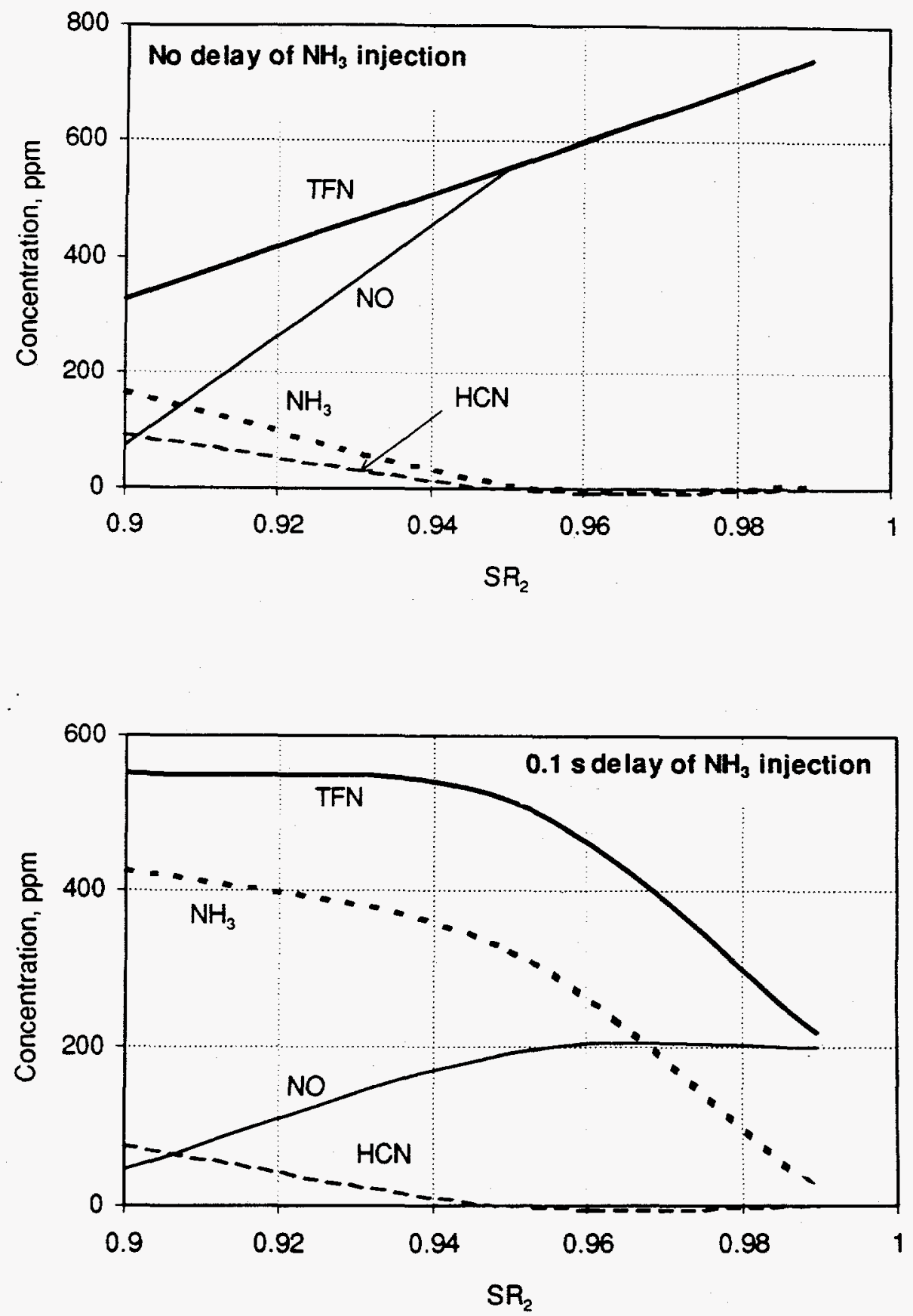

Figure 2.2.1. Effect of ammonia co-injection with the reburning fuel and $0.1 \mathrm{~s}$ delayed $\mathrm{NH}_{3}$ injection on fuel- $\mathrm{N}$ species in the reburning zone. $\left[\mathrm{NH}_{3}\right]=600 \mathrm{ppm}, \mathrm{NO}_{\mathrm{i}}=600 \mathrm{ppm}, \mathrm{T}_{1}=1700 \mathrm{~K}$. 
slowly at $\mathrm{SR}_{2}=0.90$ since most of the oxygen reacts with the high concentration of $\mathrm{CH}_{4}$. Some $\mathrm{CH}_{4}$ (about $400 \mathrm{ppm}$ ) remains unreacted in the reburning zone. At $\mathrm{SR}_{2}=0.99$, all $\mathrm{NH}_{3}$ and $\mathrm{CH}_{4}$ are instantly oxidized since the concentration of $\mathrm{O}_{2}$ is the same, but the $\left[\mathrm{CH}_{4}\right]$ level is much lower. In this oxidation process, ammonia forms some additional NO, and this NO cannot be decreased in the reaction with ammonia since it is no longer present in the mixture. Therefore, $T F N=N_{i}=742$ ppm, i.e. the NO concentration increases.

The picture is completely different if ammonia is injected with a $0.1 \mathrm{~s}$ delay time, second graph in Figure 2.2.1. In this case, at $\mathrm{SR}_{2}=0.90$, ammonia is injected when the $\mathrm{O}_{2}$ concentration is already reduced to zero (about $0.01 \mathrm{ppm}$ ). Concentration of NO is reduced in the first rapid reburning stage within the delay time of $0.1 \mathrm{~s}$ and it decreases further utilizing some ammonia. However, in $0.5 \mathrm{~s}$ the $\mathrm{NH}_{3}$ concentration is still high, about $420 \mathrm{ppm}$, and it does not react rapidly with NO since there is no oxygen to feed the radical pool. At $\mathrm{SR}_{2}=0.99, \mathrm{NH}_{3}$ is injected when the $\mathrm{O}_{2}$ concentration is about $50 \mathrm{ppm}$ (see $\left[\mathrm{O}_{2}\right]$ in Figure 2.1.1 at $\mathrm{t}=0.1 \mathrm{~s}$ ) and the $\mathrm{OH}$ concentration is still high. Therefore, in the presence of this oxygen level, $\mathrm{NH}_{3}$ and $\mathrm{NO}$ are capable of reacting with each other, and TFN concentration efficiently decreases. Thus, delayed ammonia injection can result, under certain conditions, in more effective NO removal. These conditions require the presence of the both reagents and some oxygen.

The effect of the delayed ammonia injection depends on many factors, such as the value of $\mathrm{SR}_{2}$, the delay time, ammonia concentration, oxygen concentration, etc. Figure 2.2.2 presents concentrations of fuel- $\mathrm{N}$ species in the reburning zone at $\mathrm{SR}_{2}=0.99$ and various delay times of ammonia injection. This graph and concentration profiles of the main species help to explain the effect of ammonia on NO removal. If ammonia is injected along with the reburning fuel, it rapidly disappears in the reaction with the high amount of oxygen and causes some NO formation. As was demonstrated in Section 2.1 , the initial stage of reburning is fast and forms high concentrations of radicals. Therefore, injection of ammonia with a short delay time results in $\mathrm{NH}_{3}-\mathrm{O}_{2}$ interaction in the presence of the radicals and small amounts of oxygen. This interaction efficiently reduces concentrations of NO and TFN. If ammonia is injected with a longer delay time, $\mathrm{NH}_{3}$ and $\mathrm{NO}$ interact in the media with lower radical (and $\mathrm{O}_{2}$ ) concentrations. As a result, the efficiency of NO and TFN removal is lower. 


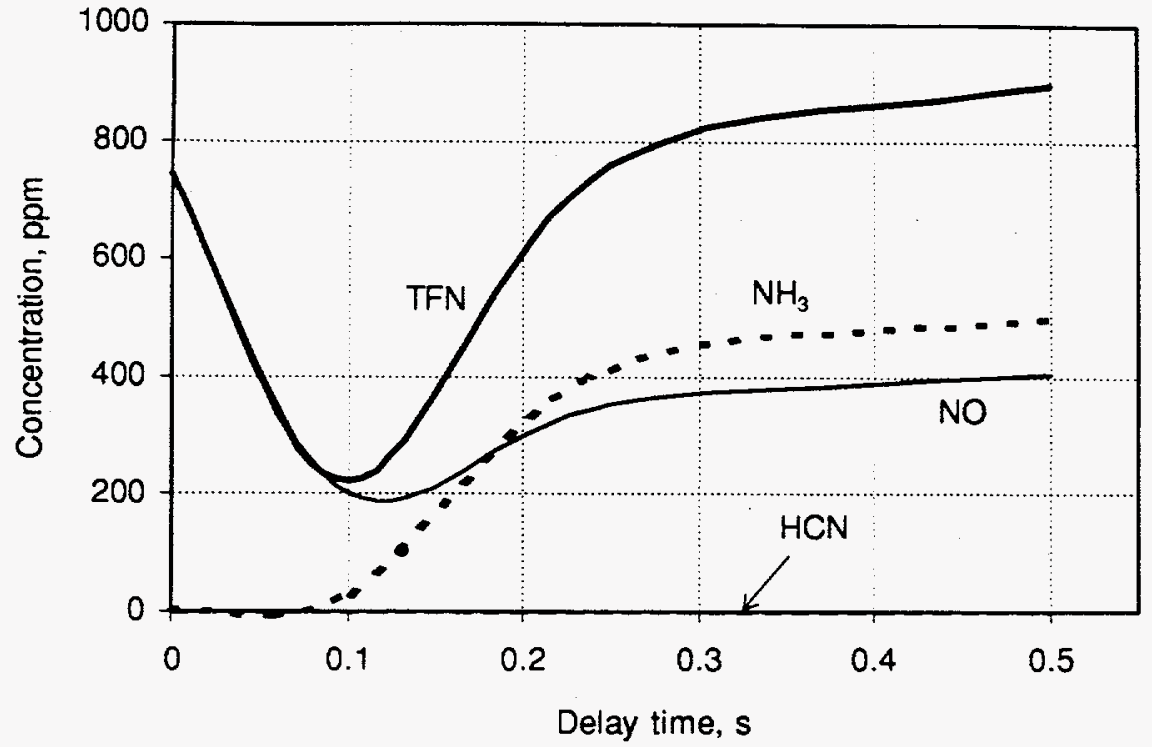

Figure 2.2.2. Effect of the delay time of $\mathrm{NH}_{3}$ injection into the reburning zone at $\mathrm{SR}_{2}=0.99$. Other conditions are the same as in Figure 2.2.1.

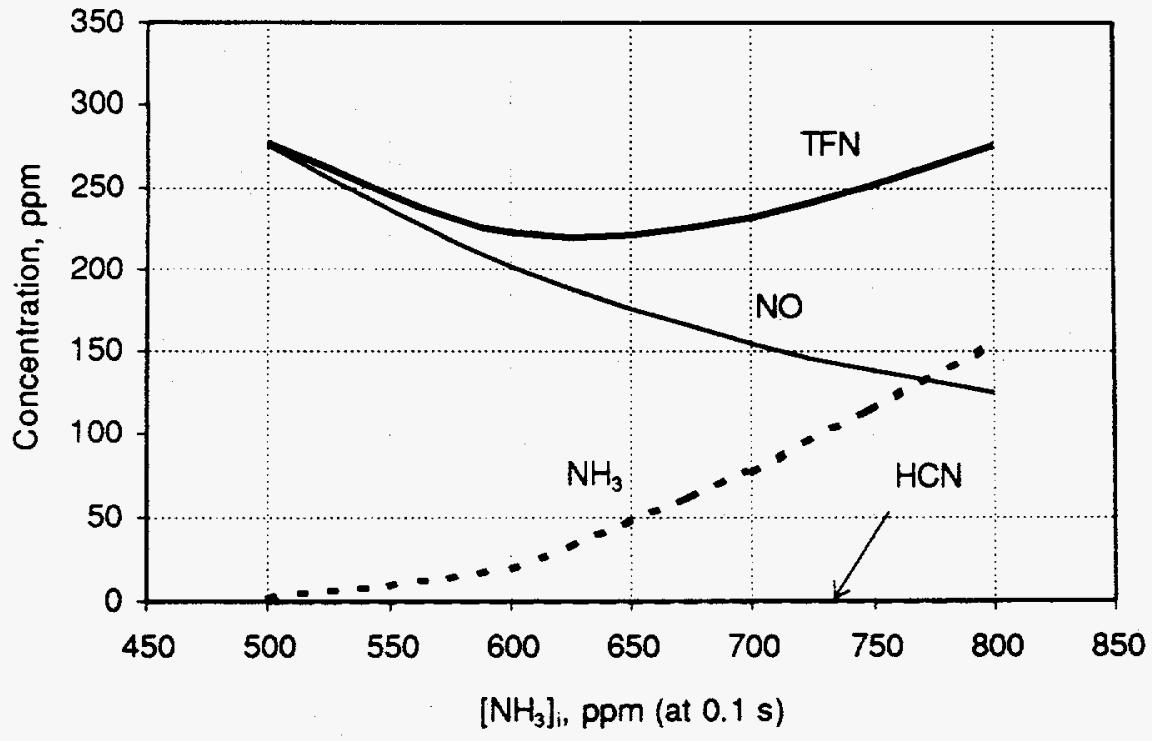

Figure 2.2.3. Effect of the $\mathrm{NH}_{3}$ concentration injected into the reburning zone at $\mathrm{SR}_{2}=0.99$ and $0.1 \mathrm{~s}$ delay time. Other conditions are the same as in Figure 2.2.1. 
Figure 2.2.3 demonstrates how NO and TFN depend on $\mathrm{NH}_{3}$ concentration injected with a $0.1 \mathrm{~s}$ delay time at $\mathrm{SR}_{2}=0.99$. At a higher level of $\left[\mathrm{NH}_{3}\right]$ injected, the NO concentration decreases, but the residual $\left[\mathrm{NH}_{3}\right]$ increases. The TFN concentration has a minimum which approximately corresponds to equimolecular amounts of $\mathrm{NO}$ and $\mathrm{NH}_{3}$ in the gas mixture $\left(\mathrm{NSR}_{1}=1.0-1.3\right)$.

Figure 2.2.4 compares performance of the reburning process at $\mathrm{SR}_{2}=0.99$ in the presence of $\mathrm{NH}_{3}$ in the reburning zone under different conditions of $\mathrm{NH}_{3}$ injection (curves 1-4). Curve 1 is the initial uncontrolled NO level of $600 \mathrm{ppm}$. Curve 2 models basic reburning at $\mathrm{SR}_{2}=0.99$ when $\mathrm{CH}_{4}$ is added to the reburning zone at $1700 \mathrm{~K}$. The NO concentration decreases to $412 \mathrm{ppm}$ in $1.5 \mathrm{~s}$ (the time of OFA addition at $1255 \mathrm{~K}$ ), or about $31 \%$ NO reduction. Curve 3 shows that if $800 \mathrm{ppm} \mathrm{NH}_{3}$ is added simultaneously with the reburning fuel, the NO concentration is rapidly increased to $900 \mathrm{ppm}$ and then reduced to $500 \mathrm{ppm}$ in $1.5 \mathrm{~s}$. Thus, the addition of $\mathrm{NH}_{3}$ in the presence of oxygen initially increases the NO concentration, but by the time of OFA injection, [NO] is close to the level achieved by the basic reburning process. High oxygen concentration prevents NO reduction because the added $\mathrm{NH}_{3}$ burns rapidly in the presence of $\mathrm{O}_{2}$ to form additional NO. If ammonia is added not with the reburning fuel, but after the $\mathrm{O}_{2}$ concentration has decreased through reaction with the reburning fuel, the efficiency of $\mathrm{NO}$ removal is much higher: $0.1 \mathrm{~s}$ delayed $\mathrm{NH}_{3}$ injection in curve 4 . In $1.5 \mathrm{~s}$ of the reaction time, the NO concentration drops to $113 \mathrm{ppm}$, but $144 \mathrm{ppm} \mathrm{NH}_{3}$ is left in the reaction media, and thus, $\mathrm{TFN}=257 \mathrm{ppm}$ as shown in Figure 2.2.4. Concentration of $\mathrm{HCN}$ was below $1 \mathrm{ppm}$ under all process conditions with $\mathrm{SR}_{2}=0.99$. Injection of $\mathrm{OFA}$ at $1255 \mathrm{~K}$ resulted in $230 \mathrm{ppm}$ final $\mathrm{NO}$ concentration, $62 \%$ NO reduction.

At higher RF concentration ( $\mathrm{SR}_{2}=0.90$ ), modeling shows formation of $229 \mathrm{ppm}$ TFN in $1.5 \mathrm{~s}(70 \mathrm{ppm}$ $\mathrm{HCN}, 115 \mathrm{ppm} \mathrm{NH}_{3}$, and $44 \mathrm{ppm} \mathrm{NO}$ ). Injection of OFA at $1255 \mathrm{~K}$ results in a $200 \mathrm{ppm}$ final NO level, corresponding to $67 \% \mathrm{NO}$ reduction. Injection of ammonia $\left(\mathrm{NSR}_{1}=1.5\right)$ into the fuel-rich zone at $\mathrm{SR}_{2}=0.9$ with a $0.1 \mathrm{~s}$ delay time followed by OFA injection, does not significantly change the final NO level. Thus, injection of $\mathrm{N}$-agents into the reburning zone is more efficient under near stoichiometric conditions. At higher reburning fuel levels, concentrations of active radicals are lower, and most of the fuel nitrogen is present in the form of $\mathrm{NH}_{3}$ and $\mathrm{HCN}$. 


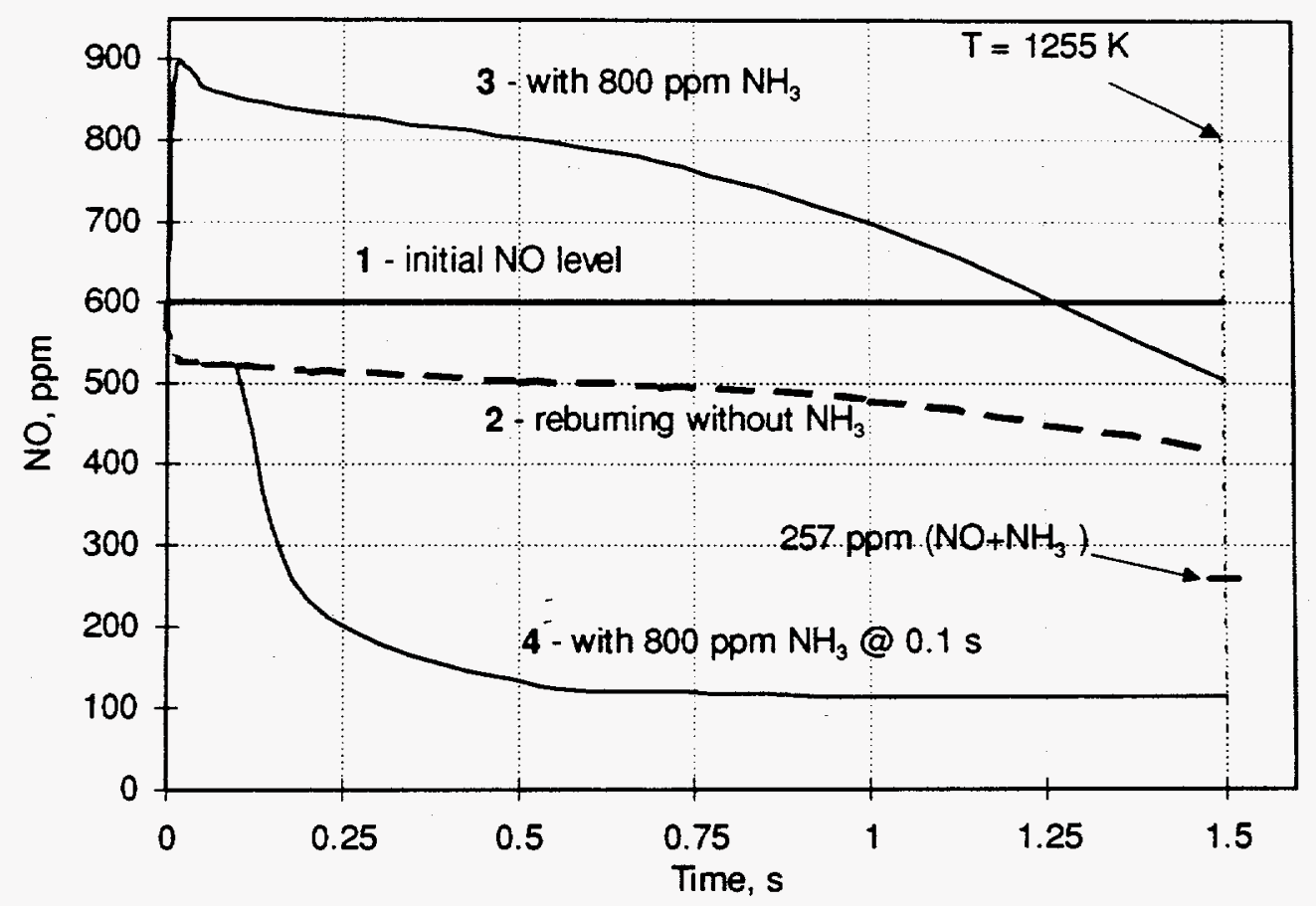

Figure 2.2.4. Effect of ammonia in the reburning zone at $\mathrm{SR}_{2}=0.99: 1$ - initial NO level, 2 reburning without ammonia, $3-800 \mathrm{ppm} \mathrm{NH}_{3}$ co-injected with the reburning fuel, 4 - $800 \mathrm{ppm}$ armmonia is added with $0.1 \mathrm{~s}$ delay time. TFN concentration ( $\mathrm{NO}+\mathrm{NH}_{3}=257 \mathrm{ppm}$ ) is shown at 1.5 $s$ (the time of OFA injection at $1255 \mathrm{~K}$ ). 


\subsection{Promotion of the NO- $\mathrm{NH}_{3}$ Interaction in the Reburning Zone}

Consideration of the kinetic curves of the reburning process (Figures 2.1.1 - 2.1.3) demonstrates that after the initial fast reaction stage, concentrations of main components in the reburning zone $\left(\mathrm{CO}, \mathrm{H}_{2}\right.$ and $\mathrm{NO}$ at $\mathrm{SR}_{2}=0.99-0.95$ and $\mathrm{CO}, \mathrm{H}_{2}, \mathrm{CH}_{4}, \mathrm{HCN}, \mathrm{NH}_{3}, \mathrm{NO}$ at $\mathrm{SR}_{2}=0.90$ ) remain almost constant, and, simultaneously, concentrations of radicals $(\mathrm{OH}$ and $\mathrm{H})$ and $\mathrm{O}_{2}$ decrease. The goal of modeling is to find conditions under which NO and TFN concentrations will decrease in the reburning zone. As was shown above, delayed injection of ammonia can reduce NO and TFN concentrations under certain conditions. The effectiveness of the $\mathrm{NO}-\mathrm{NH}_{3}$ interaction in the reburning zone can be further improved in the presence of promoters. The influence of different promoters (radicals, oxygen and fuels) on NO/TFN removal is analyzed in this Section. The second slow process in the reburning zone is considered, and parameters affecting the NO/TFN level are varied to find optimum conditions of NO/TFN removal. These parameters include the stoichiomerric ratio in the reburning zone $\left(\mathrm{SR}_{2}\right)$; RF injection temperature $\left(T_{1}\right)$; concentrations of ammonia, oxygen, radicals, and other compounds capable of promoting the $\mathrm{NO}-\mathrm{NH}_{3}$ interaction. It is clear that the influence of ammonia is different at various values of $\mathrm{SR}_{2}$. Variation of process parameters was performed for $\mathrm{SR}_{2}=0.99$ and 0.90 at a constant temperature gradient of $300 \mathrm{~K} / \mathrm{s}$. For all conditions, concentrations are shown at a reaction time of $1 \mathrm{~s}$.

Initial modeling results on promotion of $\mathrm{NO}^{-\mathrm{NH}_{3}}$ interaction in the reburning zone were obtained for injection of $\mathrm{RF}$ to provide $\mathrm{SR}_{2}=0.99$. After the first fast reaction stage, all $\mathrm{CH}_{4}$ was consumed, and concentrations of $\mathrm{CO}, \mathrm{H}_{2}$ and NO stabilized on a certain level. These conditions (mixture I)

$$
500 \text { ppm NO }-0.16 \% \mathrm{H}_{2}-0.23 \% \mathrm{CO}-8 \% \mathrm{CO}_{2}-15 \% \mathrm{H}_{2} \mathrm{O} \text { - balance } \mathrm{N}_{2}
$$

were considered as initial ones for the modeling study, and they correspond to the reaction time of about $0.1 \mathrm{~s}$ in Figure 2.1.1. At this initial point, ammonia and different promoters were added to mixture I.

Effect of ammonia addition to mixture $\mathrm{I}$ is shown in Figure 2.3.1. Without $\mathrm{NH}_{3}$ injection (the upper 

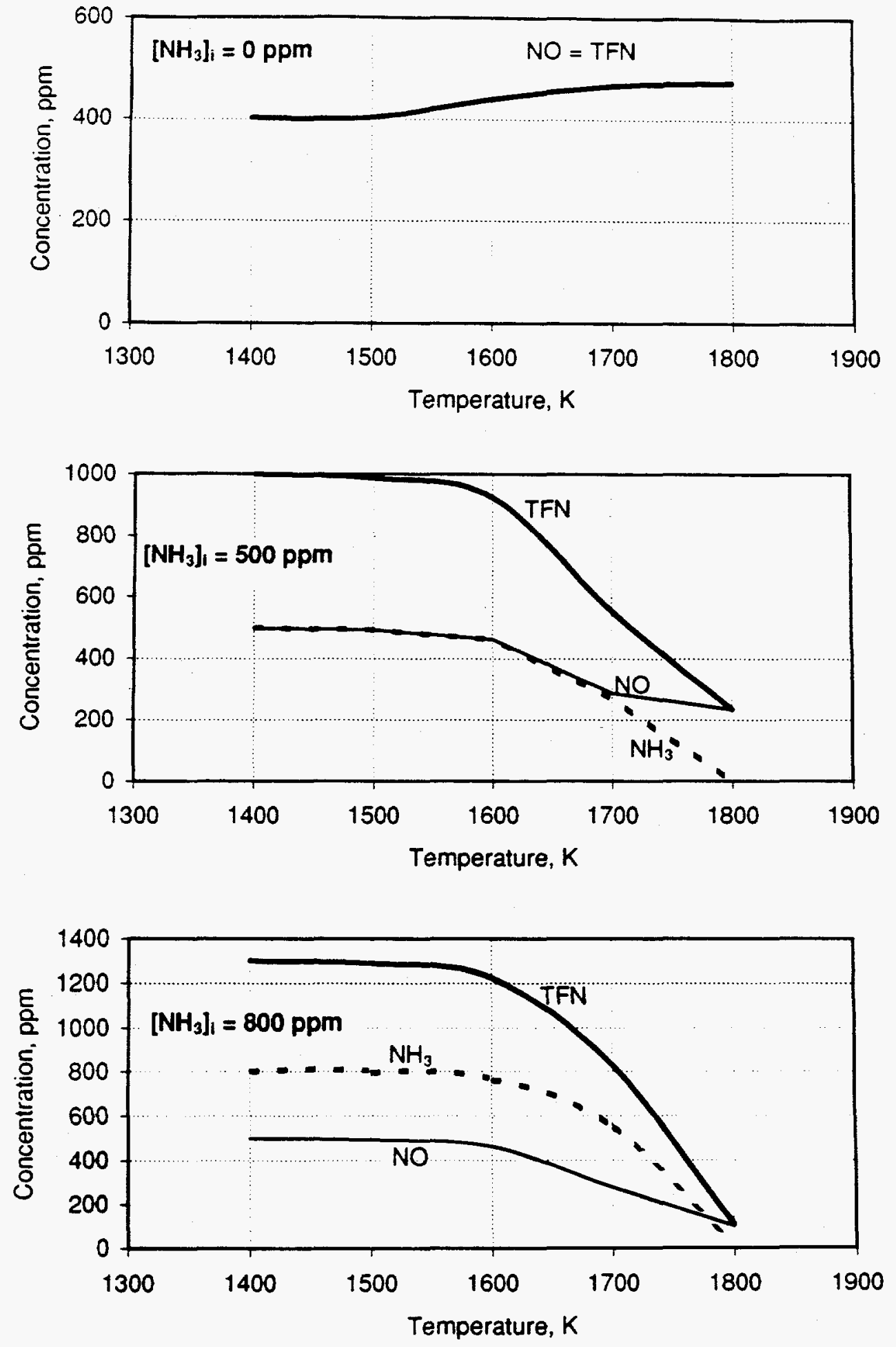

Figure 2.3.1. Effect of $\mathrm{NH}_{3}$ injection temperature and $\mathrm{NH}_{3}$ concentration in mixture $\mathrm{I}$ on NO/TFN reduction. 
graph), $\mathrm{NO}$ is slightly reduced at lower $\mathrm{NH}_{3}$ injection temperature. Injections of 500 and $800 \mathrm{ppm}$ $\mathrm{NH}_{3}$ (two other graphs) cause a TFN increase at lower temperatures and significant NO/TFN reduction at higher temperatures: 234 and $108 \mathrm{ppm}$ TFN at $1800 \mathrm{~K}$ for 500 and $800 \mathrm{ppm} \mathrm{NH}_{3}$ injection, respectively.

Performance of ammonia in the reburning zone greatly depends on the level of oxygen. If the oxygen concentration is high, $\mathrm{NH}_{3}$ is partially converted to NO. If oxygen concentration is low, active radicals are not formed in oxidation processes. Thus, a maximum performance of NO/TFN removal should correspond to a certain optimum $\mathrm{O}_{2}$ concentration. To determine this optimum $\mathrm{O}_{2}$ concentration, calculations were performed with injection of $500 \mathrm{ppm} \mathrm{NH}_{3}$ with various amounts of oxygen into mixture I. Figure 2.3.2 demonstrates the results. The optimum $\mathrm{O}_{2}$ amounts depend on injection temperature and vary from $50 \mathrm{ppm}$ at $1500 \mathrm{~K}$ to $120 \mathrm{ppm}$ at $1700 \mathrm{~K}$. Performance of TFN removal is greater at lower injection temperature: minimum TFN concentrations are $170 \mathrm{ppm}$ at 1700 $\mathrm{K}$ and about $100 \mathrm{ppm}$ at $1500 \mathrm{~K}$.

Performance of other possible promoters was modeled by the same means: radicals $(\mathrm{OH}$ and $\mathrm{H})$ and other compounds were co-injected with ammonia in different amounts into mixture I at $1600 \mathrm{~K}$. Figure 2.3.3 compares effect of different additives: $\mathrm{O}_{2}, \mathrm{OH}, \mathrm{H}, \mathrm{O}, \mathrm{O}_{2}+\mathrm{OH}$, and $\mathrm{O}_{2}+\mathrm{H}_{2} \mathrm{O}_{2}$. Though these promoters show different degrees of TFN removal, they perform not better than the injection of oxygen. Thus, oxygen participating in formation of different radicals via reactions with $\mathrm{CO}, \mathrm{H}_{2}$ and $\mathrm{NH}_{3}$, shows better or about the same performance as other additives.

All promotive additives presented in Figure 2.3.3 were co-injected with ammonia, and thus, they appeared instantly in the gas phase. However, under real conditions, the promoters may be formed in the mixture with a certain rate constant. As has been proven by Zamansky and Borisov, 1992, the rate of promoter formation may be optimum, i.e. formation of promoters with a certain optimum rate constant results in maximum promotion effect. It was assumed for modeling that a hypothetic promoter $\mathrm{X}$ dissociates with formation of radicals or oxygen in the gas mixture. The following reaction was added to the mechanism: 

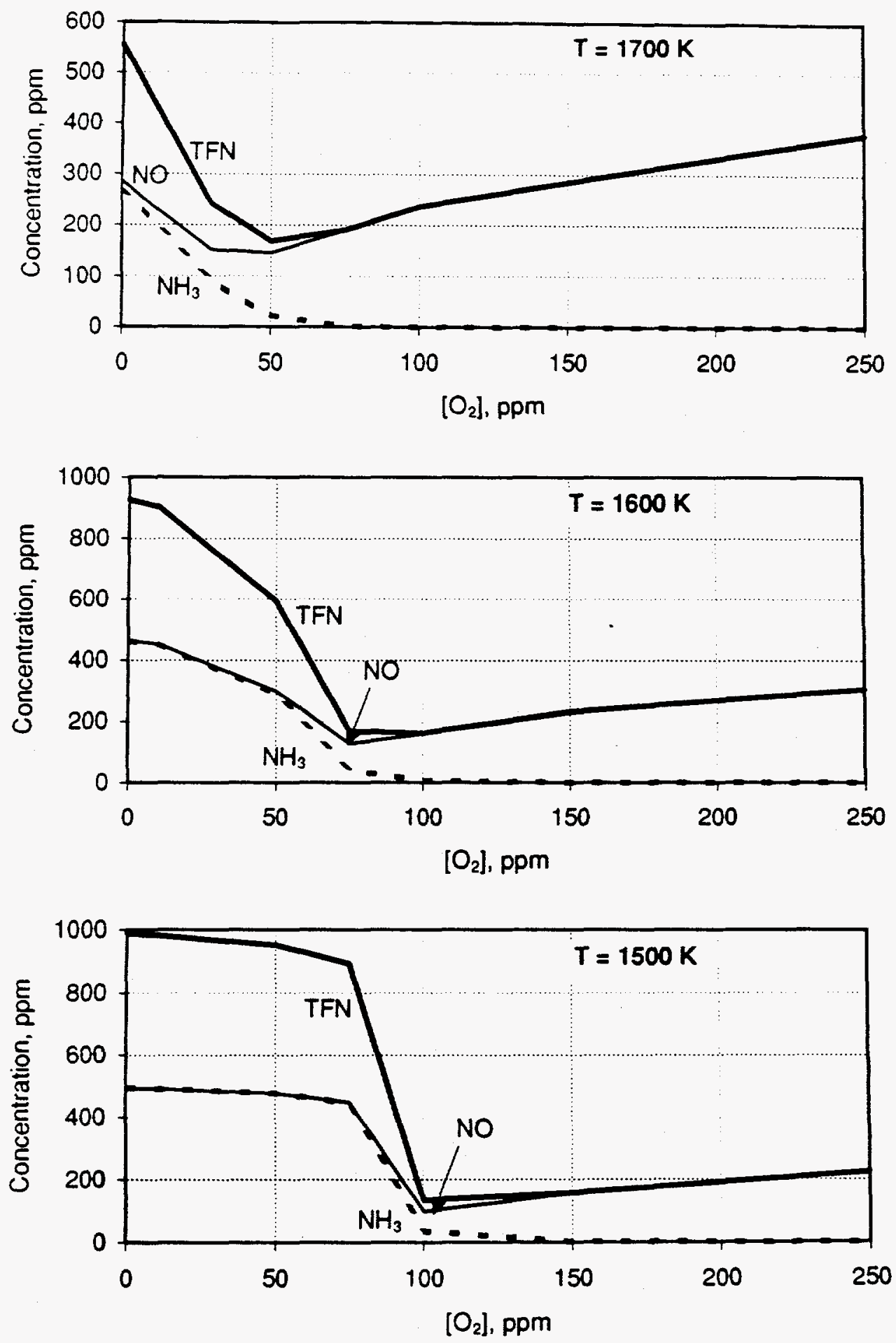

Figure 2.3.2. Effect of oxygen co-injection with $500 \mathrm{ppm} \mathrm{NH}_{3}$ into mixture I at different injection temperatures. 

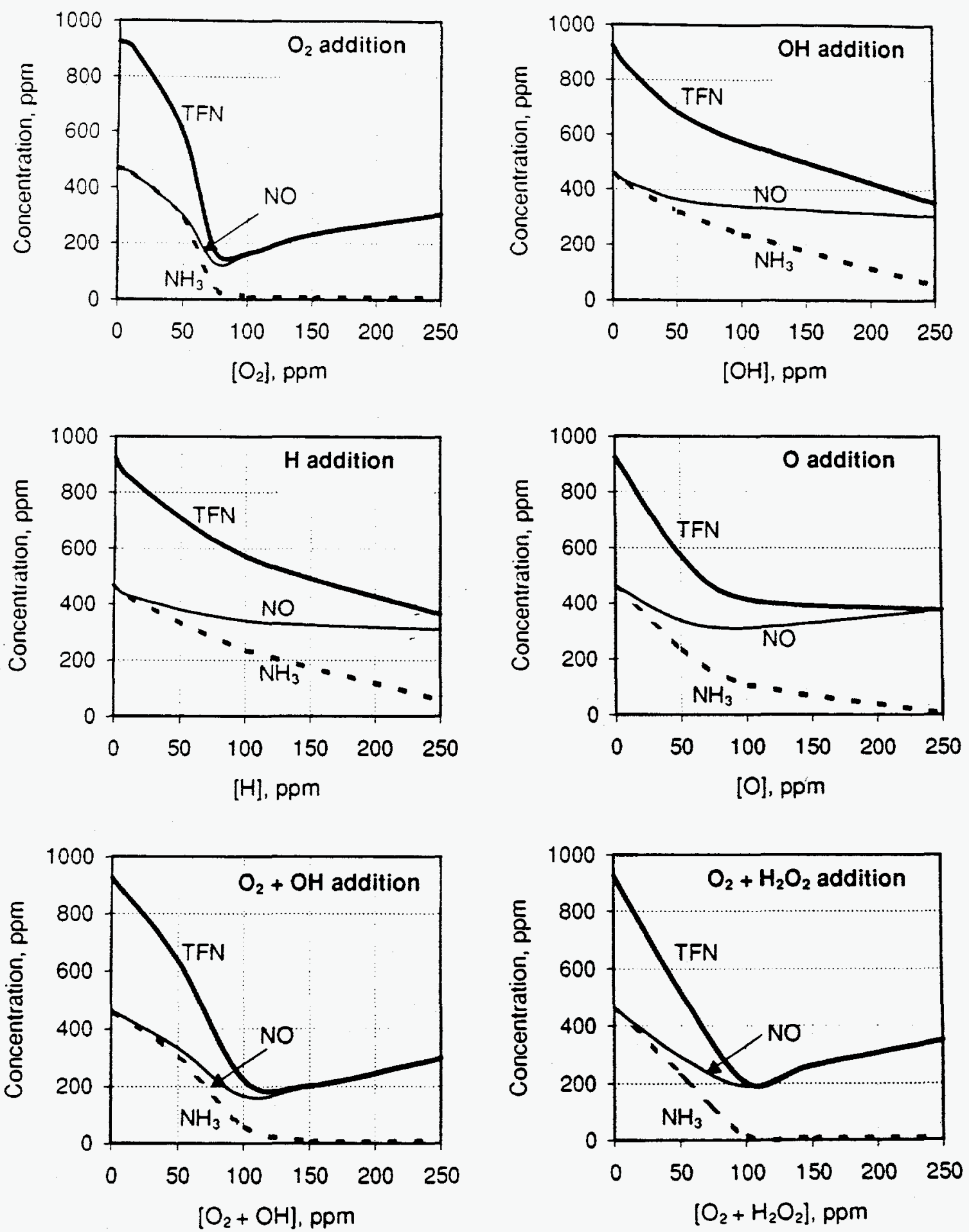

Figure 2.3.3. Effect of radicals co-injection with $500 \mathrm{ppm} \mathrm{NH}_{3}$ into mixture $\mathrm{I}, \mathrm{T}_{2}=1600 \mathrm{~K}$. 


$$
\begin{aligned}
& X+M=>\mathrm{OH}+\mathrm{H}+\mathrm{M} \quad \text { or } \\
& X+M=>\mathrm{O}_{2}+M
\end{aligned}
$$

These equations simulate fast interaction of the hypothetic promoter $X$ with water molecules or other species in flue gas with formation of $\mathrm{OH}, \mathrm{H}$, and $\mathrm{O}_{2}$. The initial concentration of $\mathrm{X}$ was assumed to be $50 \mathrm{ppm}$ in modeling. The rate constant for $\mathrm{X}$ decomposition was selected in the Arrenius form

$$
\mathrm{k}=\mathrm{A} \cdot \exp (-20,000 / \mathrm{T}) \mathrm{cm}^{3} / \mathrm{mol} \cdot \mathrm{s}
$$

where the predexponential factor $\mathrm{A}$ was varied in the range from $10^{9}$ to $10^{13}$. These values of the rate constant provided formation of radicals and $\mathrm{O}_{2}$ with characteristic times between approximately 0.1 and $100 \mathrm{~s}$.

Figure 2.3.4 compares the results of modeling $\mathrm{NO}, \mathrm{NH}_{3}$ and TFN concentrations at different values of the factor $\mathrm{A}$ (i.e. depending on the rate of active species formation in the mixture) for three different cases: formation of $\mathrm{OH}+\mathrm{H}$ radicals, formation of $\mathrm{O}_{2}$, and formation of the $\mathrm{OH} / \mathrm{H}$ radicals with co-injection of $\mathrm{NH}_{3}$ and $75 \mathrm{ppm} \mathrm{O}_{2}$. In a wide range of the promoter decomposition rate, $\mathrm{NO}$ and TFN concentrations are substantially lower than their values without promoter. In all cases, an optimum rate constant exists which results in minimum TFN concentration. The optimum factor A is in the range $\log \mathrm{A}=10.5-12.0$. Oxygen formation and co-injection present the most attractive cases because the TFN minimum is lower.

Carbon-containing compounds can also provide radicals which promote the $\mathrm{NO}-\mathrm{NH}_{3}$ interaction in the reburning zone. Effect of different potential promoters on concentrations of $\mathrm{NO}, \mathrm{NH}_{3}$ and TFN is shown in Figure 2.3.5. This graph compares the effect of $500 \mathrm{ppm} \mathrm{NH}_{3}$ injection into mixture I at $1600 \mathrm{~K}$ with co-injection of $100 \mathrm{ppm}$ promoter: oxygen, methanol, methane, ethylene or ethane. One can see that the presence of oxygen provides best performance in comparison with other conditions examined. 

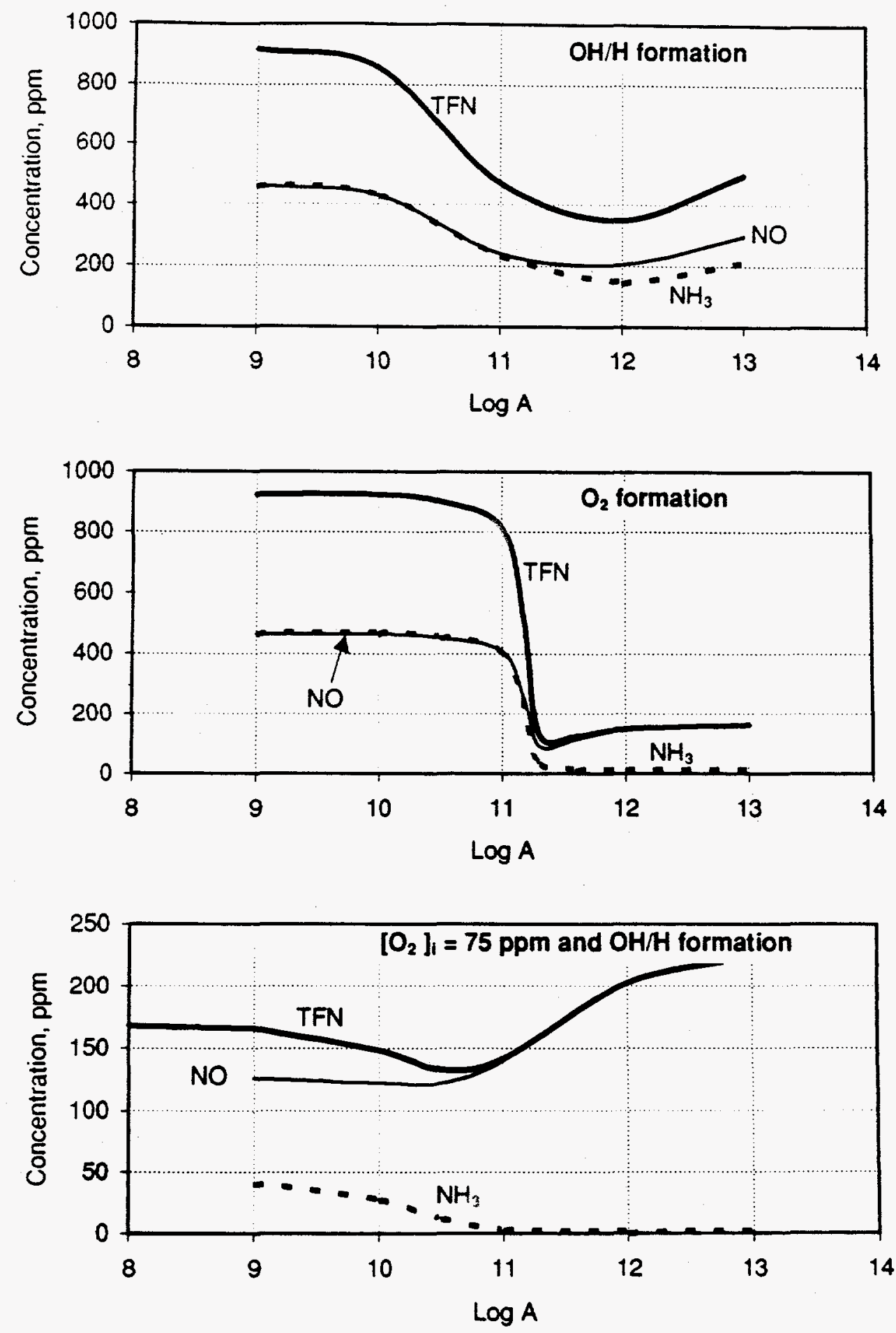

Figure 2.3.4. Modeling of the promotion effect at different predexponential factors $\mathrm{A}$. The promoter appears with different rate constants in mixture $\mathrm{I}+500 \mathrm{ppm} \mathrm{NH}_{3}$ at $\mathrm{T}_{1}=1600 \mathrm{~K}$. 


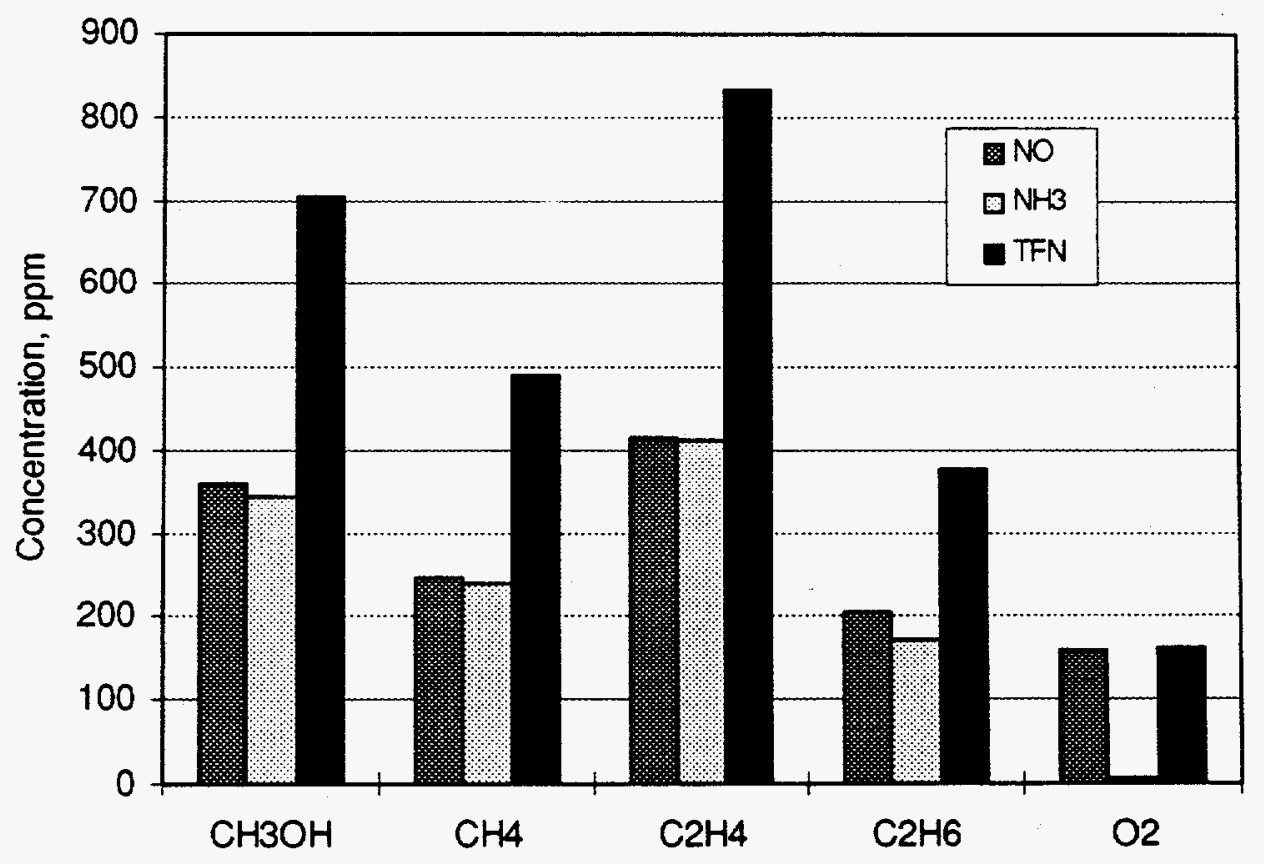

Figure 2.3.5. Comparison of the promotion effect of different compounds. The promoter $(100 \mathrm{ppm})$ is co-injected with $500 \mathrm{ppm} \mathrm{NH}$ into mixture $\mathrm{I}$ at $\mathrm{T}_{1}=1600 \mathrm{~K}$ and $\mathrm{SR}_{2}=0.99$. 
The modeling study makes it possible to select optimal conditions for reburning at $\mathrm{SR}_{2}=0.99$. The calculated NO concentration profile under optimum conditions is shown in Figure 2.3.6, Curve 4. Figure 2.3.6 compares performance of the reburning process at $\mathrm{SR}_{2}=0.99$ in the presence of $\mathrm{NH}_{3}$, similar to Figure 2.2.4, but it represents conditions with highest performance achieved in modeling. The initial fast TFN reduction process is more efficient at lower temperature (Figure 2.1.7). Therefore, one can select a temperature of $1500 \mathrm{~K}$ for RF injection. This provides about $30 \%$ NO/TFN reduction, Curve 1. The NO concentration decreases to $400 \mathrm{ppm}$ in $0.5 \mathrm{~s}$. Curve 2 represents co-injection of $600 \mathrm{ppm} \mathrm{NH}_{3}$ with the reburning fuel. The $\mathrm{NO}$ concentration drops, then slightly increases and finally slowly decreases to $480 \mathrm{ppm}$ in $0.5 \mathrm{~s}$. Curve 3 models injection of 500 $\mathrm{ppm} \mathrm{NH}_{3}$ after a $0.1 \mathrm{~s}$ delay time. In $0.5 \mathrm{~s}$ of the reaction time, the NO concentration drops to about $350 \mathrm{ppm}$.

Finally, if $500 \mathrm{ppm} \mathrm{NH}_{3}$ and $100 \mathrm{ppm} \mathrm{O}_{2}$ are injected with the $0.1 \mathrm{~s}$ delay time (Curve 4), the NO concentration decreases to $113 \mathrm{ppm}$ and only $29 \mathrm{ppm} \mathrm{NH}_{3}$ is left in the reaction media. Injection of OFA at $1320 \mathrm{~K}$ results in $138 \mathrm{ppm}$ NO in the mixture as shown in Figure 2.3.6. These optimum condition cause $68 \%$ NO reduction by delayed injection of ammonia with the oxygen promoter into the reburning zone.

Kinetic curves of components in the reburning zone at $\mathrm{SR}_{2}=0.90$ and $\mathrm{T}_{1}=1700 \mathrm{~K}$ are shown in Figures 2.1.3 and 2.1.5. The principal difference with the $\mathrm{SR}_{2}=0.99$ case is that the reburning process is more efficient and there are three fuel- $\mathrm{N}$ products in the reburning zone: $\mathrm{NO}, \mathrm{HCN}$, and $\mathrm{NH}_{3}$. For instance, at $\mathrm{t}=0.5 \mathrm{~s}$ (Figure 2.1.3) their concentrations are the following: $\mathrm{NO}=67 \mathrm{ppm}$, $\mathrm{HCN}=76 \mathrm{ppm}, \mathrm{NH}_{3}=116 \mathrm{ppm}$, and TFN $=259 \mathrm{ppm}$. Concentration of the internally formed $\mathrm{NH}_{3}$ is higher in modeling than that of $\mathrm{NO}$ and therefore, $\mathrm{NH}_{3}$ injection is not necessary for further $\mathrm{NO}$ removal. One can notice (Figure 2.1.3) that $\mathrm{O}_{2}$ disappears within first $0.02 \mathrm{~s}$ and concentrations of $\mathrm{H}$ and $\mathrm{OH}$ are lower than at $\mathrm{SR}_{2}=0.99$ and 0.95 (Figures 2.1.1 and 2.1.2, respectively). Therefore, the reaction between the available $\mathrm{NH}_{3}$ and $\mathrm{NO}$ does not proceed, and their concentrations are almost constant within reaction times from 0.1 to $0.5 \mathrm{~s}$. To activate the internal $\mathrm{NH}_{3}$, active species should be regenerated in the reburning zone and injection of oxygen can help to do it. 


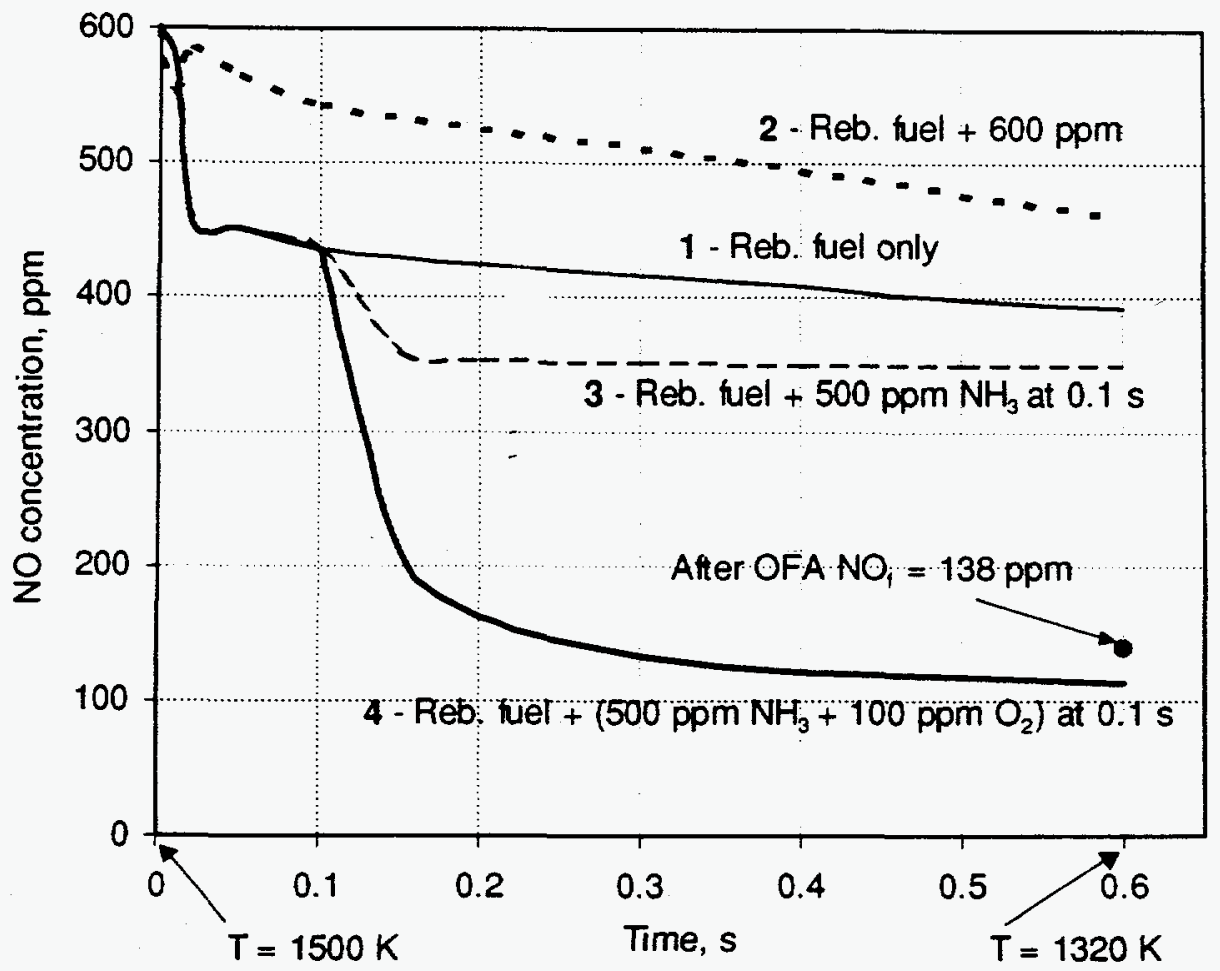

Figure 2.3.6. Optimum conditions for $\mathrm{NO}$ removal at $\mathrm{SR}_{2}=0.99: 1$ - injection of reburning fuel only at $1500 \mathrm{~K}, 2$ - co-injection of $500 \mathrm{ppm}$ ammonia with the reburning fuel, 3 - injection of 500 ppm $\mathrm{NH}_{3}$ with a $0.1 \mathrm{~s}$ delay time, 4 - delayed injection of $500 \mathrm{ppm}$ ammonia with $100 \mathrm{ppm} \mathrm{O}_{2}$. Final NO concentration $\left(\mathrm{NO}_{\mathrm{f}}=138 \mathrm{ppm}\right)$ is shown at the time of OFA injection at $1320 \mathrm{~K}$. 
Figure 2.1.7 shows that at $\mathrm{SR}_{2}=0.90$ the efficiency of reburning is higher at higher $\mathrm{RF}$ injection temperature. Therefore, modeling was conducted at $T_{1}=1700 \mathrm{~K}$. Different amounts of oxygen were injected in the reburning zone with various delay times. Figure 2.3.7 demonstrates the resulting concentrations of $\mathrm{CO}, \mathrm{H}_{2}$ and fuel- $\mathrm{N}$ species for injection of oxygen into the reburning zone at 1600 $\mathrm{K}$ that corresponds to a $0.33 \mathrm{~s}$ delay time. Concentrations are shown at $\mathrm{t}=1.0 \mathrm{~s}$, i.e. $\mathrm{T}=1300 \mathrm{~K}$. TFN concentration has a wide minimum in the range of oxygen level between 0.1 and $0.6 \%$. TFN can be reduced to about $85 \mathrm{ppm}$ if $0.3-0.4 \% \mathrm{O}_{2}$ is injected into the reburning zone. This concentration corresponds to a fuel rich mixture with $\mathrm{CO} / \mathrm{H}_{2}$ concentrations within $1.5-1.8 \%$ range. Injection of higher $\mathrm{O}_{2}$ concentrations causes less efficient TFN removal and at $\left[\mathrm{O}_{2}\right]=2 \%$, all $\mathrm{CO}$ and $\mathrm{H}_{2}$ species are consumed and some oxygen, about $150 \mathrm{ppm}$, is present in the mixture at the reaction time of $1 \mathrm{~s}$. 

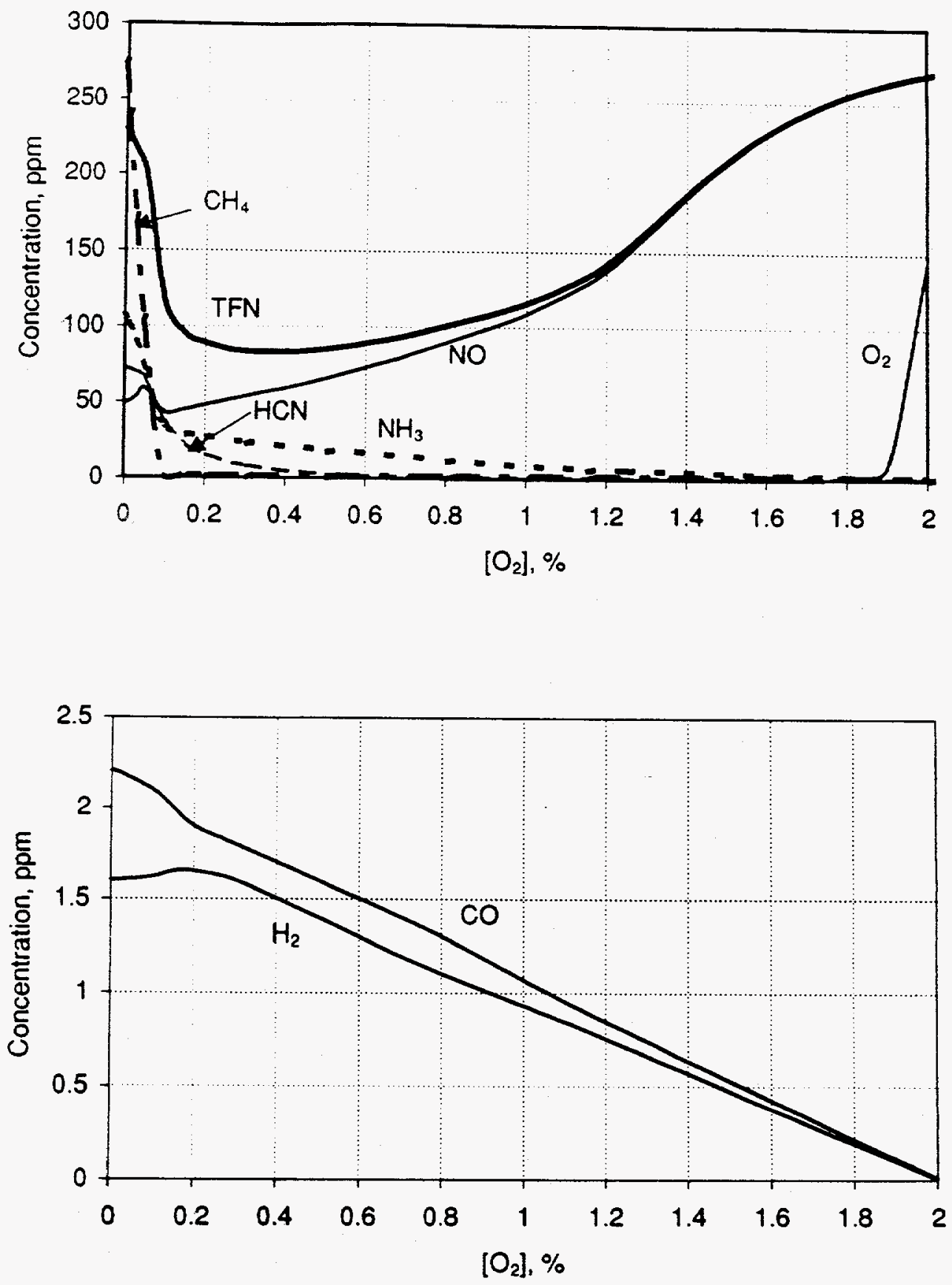

Figure 2.3.7. Efficiency of reburning at $\mathrm{SR}_{2}=0.90$ and $\mathrm{T}_{1}=1700 \mathrm{~K}$ depending on different $\mathrm{O}_{2}$ amounts injected with a 0.33 s delay time (at $1600 \mathrm{~K}$ ) into the reburning zone. 


\subsection{Kinetics of Sodium Reactions}

(Summary of activities at the University of Texas, March 1996)

As a subcontractor to EER, The University of Texas at Austin is responsible for the experimental study and theoretical modeling of processes of decomposition of salts of alkali metals, as proposed as prospective additives for $\mathrm{NO}_{\mathrm{x}}$ removal from flue gases. The University of Texas at Austin will also study interactions of these salts with components of flue gases $\left(\mathrm{CH}_{4}, \mathrm{CO}, \mathrm{NO}, \mathrm{NH}_{3}, \mathrm{H}_{2}, \mathrm{H}_{2} \mathrm{O}, \mathrm{O}_{2}\right.$, and $\mathrm{SO}_{\mathrm{x}}$ ). Significant experimental and modeling efforts are required for successful fulfillment of the project, and first step in coordination of theses efforts is development of a two year plan of the work. We developed the following plan for the work to be conducted at the University of Texas.

Task 1.2 Kinetics of $\mathrm{Na}_{2} \mathrm{CO}_{3}$ Reaction with Flue Gas Components, 3/96 - 9/97

General Objective: To confirm and develop the technical basis of the promotor additive Na2CO3. Quarterly Reports for periods ending: March 31, June 30, September 30, December 31

$3 / 96-6 / 96$

Literature review on $\mathrm{Na}_{2} \mathrm{CO}_{3}$ reactions at high temperatures.

Reconstruction of flow system and construction of gas handling system for gas chromatograph (GC). Quarterly Report.

$7 / 96-12 / 96$

Development of a $\mathrm{Na}_{2} \mathrm{CO}_{3}$ solution injection system, calibration of the injection system. Flow system study of $\mathrm{Na}_{2} \mathrm{CO}_{3}$ decomposition. Reactions of $\mathrm{Na}_{2} \mathrm{CO}_{3}$ with components of flue gas. Method: GC detection of $\mathrm{CO}_{2}$ and other components of flue gas.

Quarterly Reports. 
$1 / 97-3 / 97$

Kinetic modeling of $\mathrm{Na}_{2} \mathrm{CO}_{3}$ decomposition in the presence of flue gas components.

Experimental study of reactions of other sodium salts $\left(\mathrm{NaHCO}_{3}, \mathrm{CH}_{3} \mathrm{COONa}\right)$ with flue gas components.

Quarterly Report.

$4 / 97-6 / 97$

Development of a kinetic model of the reaction between $\mathrm{Na}_{2} \mathrm{CO}_{3}$ and flue gas components. Shock tube study of $\mathrm{Na}_{2} \mathrm{CO}_{3}$ reactions with flue gas components. Method: $\mathrm{GC}$ analysis of products and optical detection of $\mathrm{Na}$ atoms.

Quarterly Report.

Final Report.

A detailed literature review on the high temperature reactions of $\mathrm{Na}_{2} \mathrm{CO}_{3}$ was started in $\mathrm{March}$; the results will be reported in the next Quarterly Report. Experimental efforts were started with the construction of the flow and gas handling systems for GC analysis. The gas handling system was constructed from glass and metal components to enable high and low pressure operation. Existing GC columns were replaced with new columns packed with molecular sieves and HAYESEP Q to enable measurements of $\mathrm{CO}_{2}$ (presumed to be the main product of $\mathrm{Na}_{2} \mathrm{CO}_{3}$ decomposition) and surrogate components of flue gas.

The GC gas handling system is in operating conditions and calibrations have begun; reconstruction of the flow system to facilitate $\mathrm{Na}_{2} \mathrm{CO}_{3}$ injection has not started yet. Preliminary runs showed that the detection limit of the flame ionization detector is $50 \mathrm{ppm}$ when $\mathrm{CH}_{4}$ is taken as reference gas and that the sensitivity of the thermal conductivity detector is $600 \mathrm{ppm}$ when $\mathrm{O}_{2}$ is taken as reference gas.

In the next three months experimental efforts will be directed on reconstruction of the flow system. 


\section{0 Conclusions}

The modeling study on chemical behavior of ammonia in the reburning zone makes it possible to conclude that:

1. Injection of the reburning fuel at $\mathrm{SR}_{2}$ of about 0.90 and lower generates $\mathrm{NH}_{3}$ and $\mathrm{HCN}$, but at $\mathrm{SR}_{2}=0.99-0.92, \mathrm{NO}$ are the principal fuel- $\mathrm{N}$ species in the reburning zone. Reburning is more efficient at lower RF injection temperature within a range of $\mathrm{SR}_{2}$ between $0.99-0.95$. At higher $\mathrm{RF}$ concentrations, $\mathrm{NH}_{3}$ and $\mathrm{HCN}$ become a substantial part of fuel-N species, and the efficiency of the process becomes higher at higher RF injection temperatures.

2. There are two steps of NO reduction in the reburning zone. The first fast step, about $5 \mathrm{~ms}$ at $1700 \mathrm{~K}$, involves reactions of $\mathrm{C}$-containing radicals. Among them, $\mathrm{HCCO}$ and $\mathrm{CH}_{2}$ are the most important srecies. During the second step, NO slowly reacts with $\mathrm{N}$-species.

3. Delayed $\mathrm{NH}_{3}$ injection into the reburning zone is efficient at $\mathrm{SR}_{2}=0.95-0.99$ and the most efficient at near stoichiometric conditions, $\overline{S R}_{2}=0.99$. Short delay times, about $0.1 \mathrm{~s}$, and $\mathrm{NSR}_{1}$ of about 1.2-1.3 are preferable at $\mathrm{SR}_{2}=0.99$ and provide higher NO/TFN control efficiency.

4. At $\mathrm{SR}_{2}=0.99$, promoters, co-injected with ammonia, are capable of reducing NO concentration. Small oxygen concentrations can activate the $\mathrm{NO} / \mathrm{NH}_{3}$ interaction, and they are the most efficient among promotive additives examined. The promotion effect is higher at lower injection temperatures and at the level of $\mathrm{O}_{2}$ injected of $50-150 \mathrm{ppm}$. Formation of $\mathrm{O}_{2}$ and other promoters in the reburning zone from different additives with certain rate constants can increase NO control efficiency. Under optimum conditions at $\mathrm{SR}_{2}=0.99$, $\mathrm{NO}$ can be reduced by about $80 \%$ via promoted injection of ammonia into the reburning zone.

5. At $\mathrm{SR}_{2}=0.90$, ammonia is formed in the reburning zone and can react with $\mathrm{NO}$ if the system is activated by injection of $0.1-0.4 \% \mathrm{O}_{2}$. The oxygen injection is more efficient at small delay times of about $0.1 \mathrm{~s}$. At $S R_{2}=0.90, T F N$ concentration can by reduced via oxygen (air) injection into the reburning zone by about $88 \%$. 


\subsection{Future Plans}

The main activities of the next quarter will include continuation of the parametric experiments with the use of the bench-scale $0.1 \mathrm{MBtu} / \mathrm{hr}$ combustion facility. Modeling will be focused on ammonia injection into the burnout zone and on sensitivity analysis to define most important elementary reactions under different conditions. Experimental program at the University of Texas will also be continued. Results will be presented at the First Joint Power and Fuel Systems Contractors Conference July 9-11, 1996 in Pittsburgh and at the 1996 AFRC (American Flame Research Committee) International Symposium, Baltimore, MD, September 30 - October 2, 1996. 


\subsection{References}

Bowman, C.T., SNCR Mechanism, private communication, October, 1995.

Bowman, C.T., Hanson, R.K., Davidson, D.F., Gardiner, W.C.Jr., Lissianski, V.V., Smith, G.P., Golden, D.M., Frenklach, M., Wang, H. and Goldenberg, M., http://www.gri.org, 1995.

Kee, R.J., Rupley, F.M. and Miller, J.A., Chemkin-II: a Fortran Chemical Kinetics Package for the Analysis of Gas-Phase Chemical Kinetics, Sandia National Laboratories Report No. SAND89$8009,1989$.

Zamansky, V.M. and Borisov, A.A., Promotion of High-Temperature Self-Ignition, Prog. Energy Combust. Sci., V. 18, pp. 297-325, 1992.

Zamansky, V.M. and Maly, P.M., Second Generation Advanced Reburning for High Efficiency NOx Control, EER 1st Quarterly Report, DOE Contract No. DE-AC22-95PC95251, January, 1996. 